\title{
Identification of Geothermal Reservoirs in South Cameroon from a Combined Landsat 8 and AMT Data
}

\author{
Piameu Kwagag Joel, ${ }^{1}$ Owona Angue Marie Louise-Clotilde, ${ }^{2,3}$ Ngatchou Evariste, ${ }^{2}$ \\ Njingti Nfor, ${ }^{2}$ Kue Petou Rokis Malquaire ${ }^{D},{ }^{4,5}$ and Njandjock Nouck Philippe ${ }^{3}$ \\ ${ }^{1}$ Postgraduate School of Sciences, Technologies \& Geosciences, University of Yaoundé I, Yaoundé, Cameroon \\ ${ }^{2}$ Department of Physics, Advanced Teacher Training College, University of Yaoundé I, Yaoundé, Cameroon \\ ${ }^{3}$ Department of Physics, University of Yaoundé I, P.O. Box 812, Yaoundé, Cameroon \\ ${ }^{4}$ National Institute of Cartography, Yaoundé, Cameroon \\ ${ }^{5}$ School of Geosciences, China University of Petroleum, Qingdao, China
}

Correspondence should be addressed to Kue Petou Rokis Malquaire; rokis.petou@yahoo.fr

Received 24 July 2021; Revised 7 November 2021; Accepted 22 January 2022; Published 14 February 2022

Academic Editor: Salvatore Gambino

Copyright (c) 2022 Piameu Kwagag Joel et al. This is an open access article distributed under the Creative Commons Attribution License, which permits unrestricted use, distribution, and reproduction in any medium, provided the original work is properly cited.

\begin{abstract}
This geothermal source prospecting work is carried out in order to respond to the energy deficit affecting the populations of South Cameroon in particular. The study combines audio-magnetotelluric (AMT) and Landsat 8 data for the geolocation of reservoirs, as well as the geological and tectonic information. The processing of these data defined 5 profiles and led to two-dimensional models of resistivity sections for each profile. The interpretation of the data identified a highly conductive zone with a resistivity ranged $1-10 \Omega \cdot \mathrm{m}$ at an estimated depth of $1200 \mathrm{~m}$ in the locality of Menve'ele. The Landsat 8 data collected in this area during the same period enabled the elaboration of temperature and lineament anomaly maps of the study area. Hightemperature areas with high lineament predominance correlate better with areas of low resistivity. For example, Menve'ele (A1) has a surface temperature range of $20^{\circ} \mathrm{C}-30^{\circ} \mathrm{C}$ and a high density of lineaments. By correlating these results with those provided by previous authors, the Menve'ele locality may be the target of a potential geothermal reservoir. A 3D resistivity model is built to better understand the variations of resistivity and their depths. The geological and tectonic information of the region confirm the tectonic origin of the faults and lineaments as well as the predominance of metamorphic and sedimentary formations.
\end{abstract}

\section{Introduction}

Surface hydrothermal events are often the first indications of the possible presence of high-enthalpy geothermal energy reservoirs, and it is usually necessary to refer to geoscience to confirm their existence, characteristics, and location at depth. The information provided by geology, geochemistry, geophysics, and remote sensing complement each other and can contribute to the development of a field conceptual model that will be used to design an exploration drilling program and as a basis for a field prefeasibility study. Each of these methods evolves and benefits from theoretical advances, advances in computer science, and measurement techniques, but also from feedback, i.e., the successful application of one or more specific methods in well-defined contexts [1]. The study area is located in Southern Cameroon between parallels $2^{\circ} 20^{\prime} \mathrm{N}-3^{\circ} 20^{\prime} \mathrm{N}$ of North Latitude and meridians $9.8^{\circ} \mathrm{E}-10.8^{\circ} \mathrm{E}$ of East Longitude and covers an area of about $111 \mathrm{~km}^{2}$ (Figure 1). In recent decades, it has shown slight earthquake tremors and active extensional tectonics, which has led to an interest in seismic studies. These volcanic areas are a good indicator of the presence of a geothermal reservoir $[2,3]$. Based on seismic data obtained between February 1987 and May 1989 along the volcanic line of Cameroon in its Southwestern continental part, 


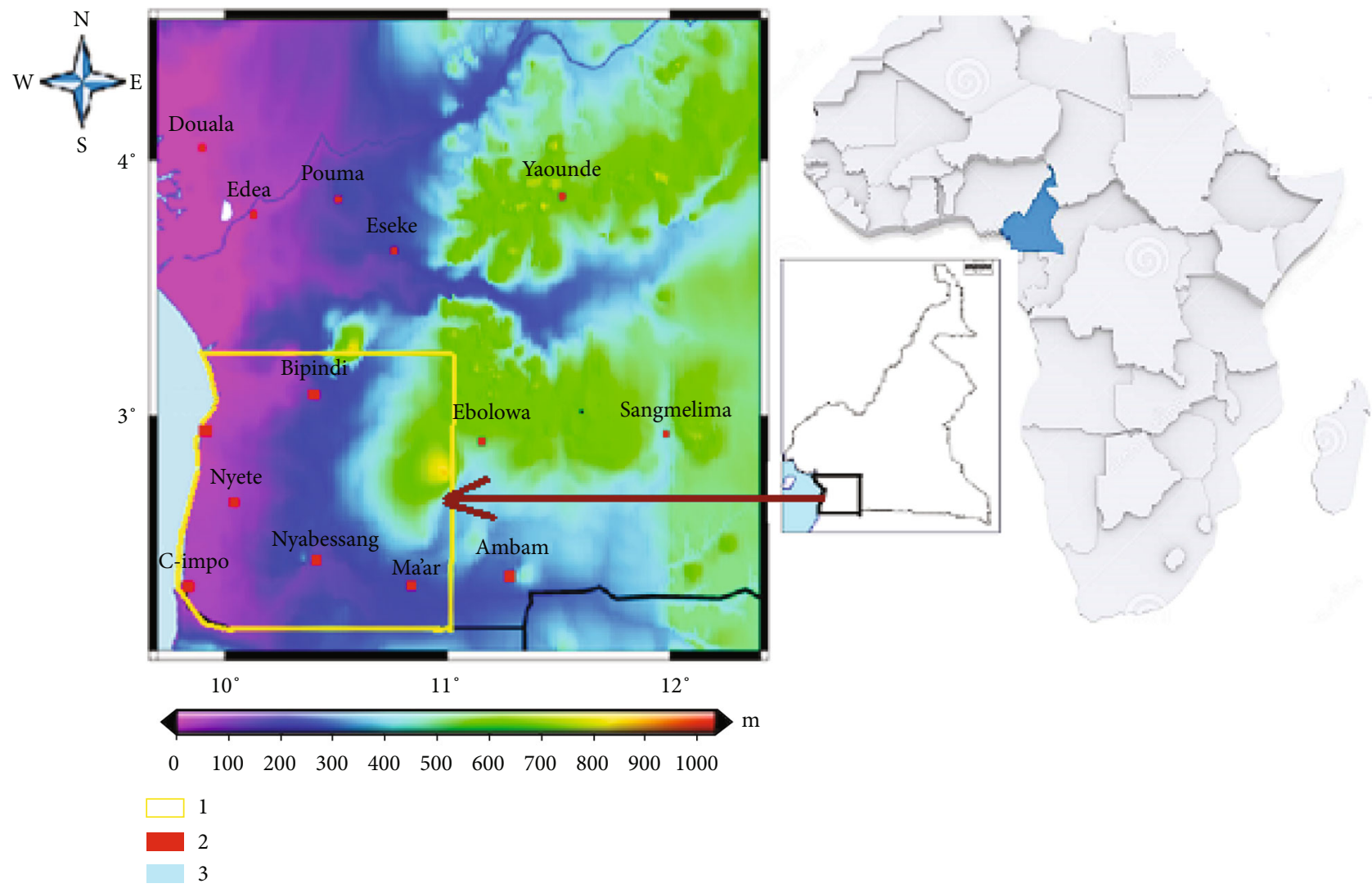

FIGURE 1: Location map of the study area.

[4] justifies that earthquakes in the vicinity of Kribi have focal depths down to $30 \mathrm{~km}$ and more.

These events could be more or less associated to the presence of the Kribi-Campo fault line. In the same order of idea, the study of [5], based on the same data, suggests a South-South West (SSW) extension of the geophysical limit of the Congo craton in the direction of Kribi; the seismicity of the region could originate from this contact between the craton and the Pan-African fault line. After the July 2020 magnitude 3.6 earthquake that occurred in Kribi, [6] analyzed the seismicity of this locality and suggested that there is tectonic activity related to the fault systems known as the Kribi-Campo fault, which is an extension of the Sanaga fault [7]. To estimate the average depth of the Moho on the cardboard at $45 \mathrm{~km}$ and under the Kribi-Campo domain at $28 \mathrm{~km}$, [8] performs a joint inversion of Rayleigh group velocities and receiver functions by analyzing seismic data from a temporary network installed in Cameroon between 2005 and 2007. In addition to these indicators, the strong predominance of faults and lineaments is conducive to the development of geothermal sites [9]. The vast network of faults identified in the South Cameroon region through the geological map (Figure 2) of [10] and highlighted by [11] with the directions (N-S, EW, SW-NE, and SSW-NNE) constitutes a major asset in the prospecting of geothermal sources. According to [12], areas of low resistive anomalies or high conductivity are favorable for the circulation of hydrothermal fluids. [13] proposes a $3 \mathrm{D}$ resistivity distribution model in the Gisenyi geothermal field in Rwanda from 69 magnetotelluric (MT) stations and show a conductive region with resistivity less than $10 \Omega \cdot \mathrm{m}$ at great depth.

This conductive body reveals to the author the heat source of the Gisenyi system. A 2D inversion of the MT data in the Al-Mubazzarah geothermal area, Al-Ain, United Arab Emirates by [14] shows a conductive zone (10-30 $\Omega$ ) located at a depth of $4 \mathrm{~km}$ that is believed to be the source of the hot groundwater. This previous work is necessary and provides a compass for future work. Despite these scientific advances in few regions [15-19], Cameroon in general and its southern part in particular faced peremptory energy deficit. In order to contribute a solution to this problem while preserving the environment, a correlative study based on the analysis of audio-magnetotelluric (AMT) and Landsat 8 satellite data measured with good spatial resolution $(10 \mathrm{~m}$ to $5 \mathrm{~m}$ ) is necessary to have more accurate and reliable information in the identification of potential geothermal sites. For this purpose, pseudomean resistivity cross-section curves are plotted on well-defined profiles as well as a $3 \mathrm{D}$ resistivity field model to observe their variation at shallow and deep depths.

\section{Geological and Tectonic setting}

2.1. Geological Settings. The study area comprises two major geological units: the Congo craton, which occupies most of the area; and a smaller part of the Campo sedimentary basin in the Pan-African belt. The major part located in the 


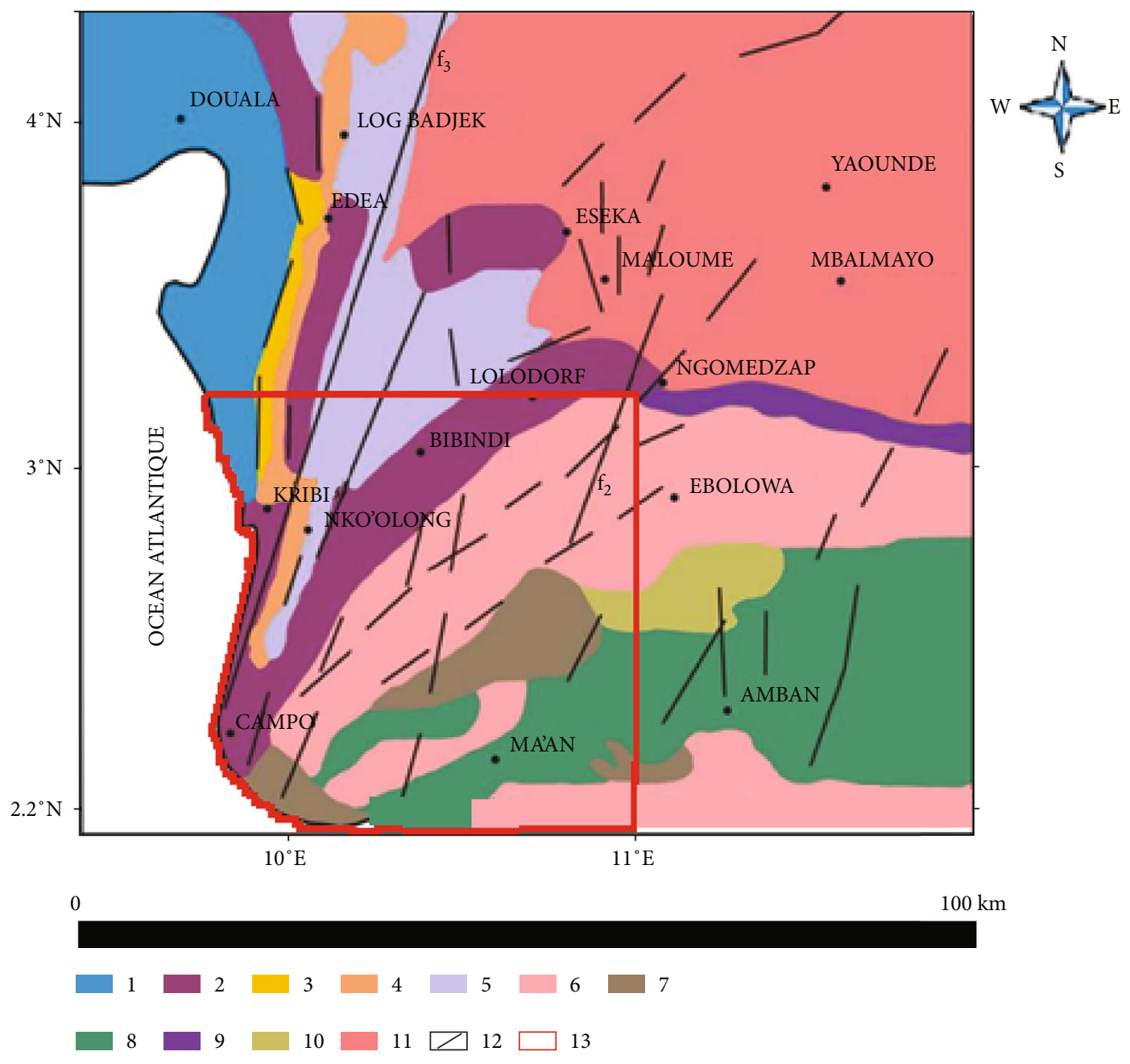

Figure 2: Geological map of the study area (Southwest Cameroon) from [10]. Cameroon Atlantic coast basins, 1: sediments. Nyong unit, 2: gneiss; 3: metagranodiorite; 4: metamorphic rocks of the Yaoundé group; and 5: green rock belt. Ntem unit, 6: charnockites; 7: green rock belt; 8: striped series; 9: tonalites; and 10: potassic granitoïdes. Yaoundé group, 11: undifferentiated metamorphic unit of the North Equatorial Pan-African belt. 12: faults f1 and f2: deep gravimetric faults [26]. F3: Kribi-Campo fault. 13: study area.

cratonic zone includes the Ntem and Lower Nyong units. The Ntem group includes geological formations such as gneiss, Archean granitoids, granites, and granodiorites as well as the greenstone belt located in the eastern sector of the study area. The Nyong unit consists of the gneiss located in the western sector (Figure 2). From a geodynamic point of view, the particularities of the Pan-African belt were highlighted in the work of $[20,21]$. According to their works, the Pan-African range in Cameroon includes a multitude of granitoids. These granitoids are mostly orthogneissified and are mainly represented by granites, leucogranites, granodiorites, syenites, gabbros, diorites, charnockites, monzonites, micaschist, granitic gneiss, quartzites of metamorphic origin, and conglomerates (sedimentary) belonging to the Yaoundé Group.

The distribution of temperature with depth (geotherm) in the continents is determined by the conductive heat transfer. In granitic terranes, just like the study area, high surface heat flow are predominant according to the basin analysis by [22], while in basic and/or ultrabasic igneous rock terranes low surface heat flow is predominant. The heat flow can be over the scale in area of volcanic rift zones, i.e., East African Rift basin and Borno (Chad) Basin.

2.2. Tectonic Settings. The tectonics of the western part are mainly dominated by large overlaps and numerous major faults, in particular, the large overlap of the Congo craton by the Yaoundé Group $[23,24]$. The seismicity of this region is thought to be due to the overlap between the Congo craton and the Pan-African belt [5]. In the basement, faults remain more difficult to identify either due to lack of sufficient outcrop or because of juxtaposition of rocks of similar features [23]. However, highly mylonitized zones and orientation of water courses often underline the existence of these faults at depth [25]. 


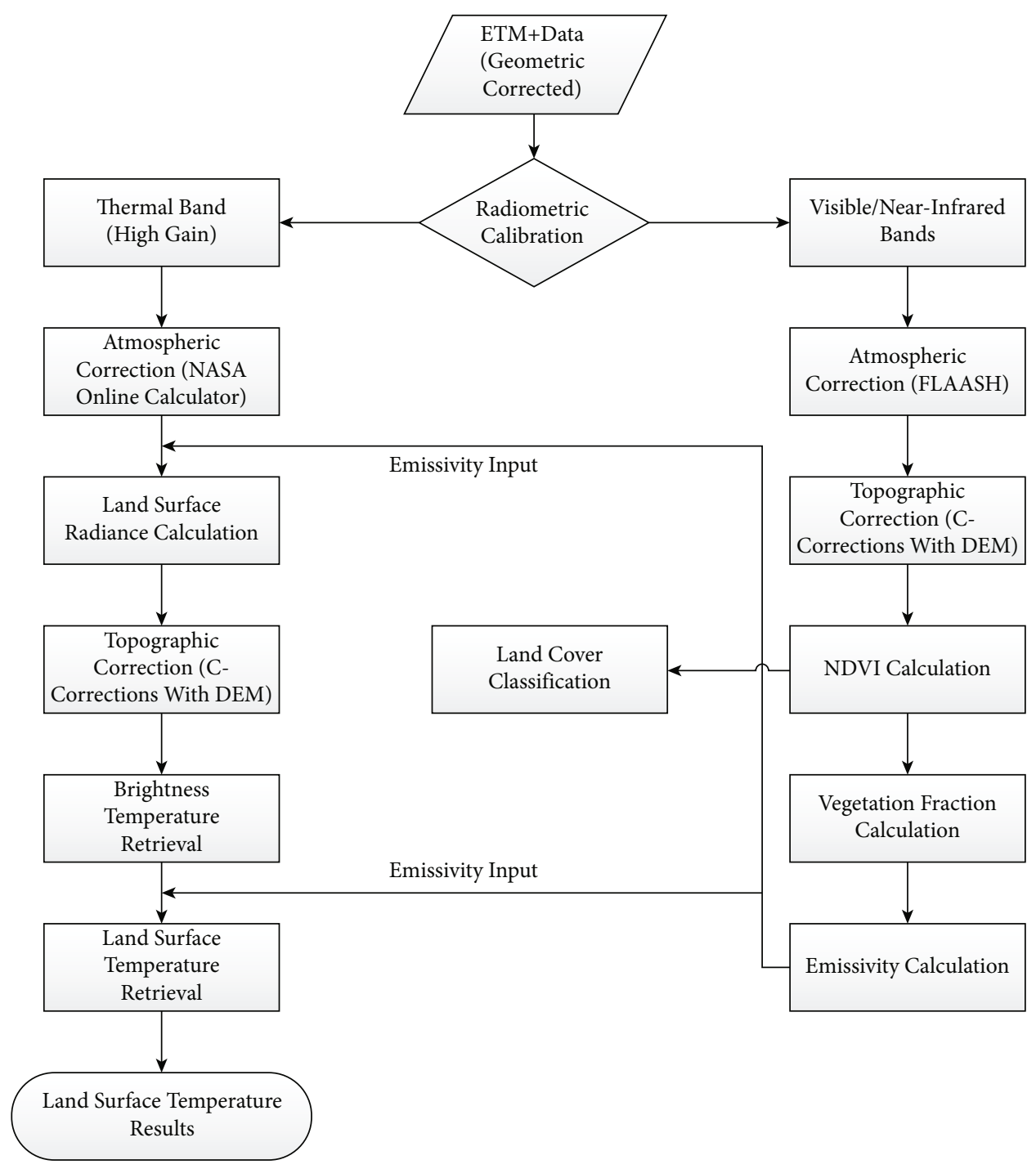

FIGURE 3: Landsat 8 data processing algorithm.

\section{Methodology and Data}

3.1. Methodology. Two methods were combined to prospect for geothermal sources by making a spatial correlation between the results provided by each of them. These methods are briefly described as follows.

3.1.1. Magnetotelluric Method. It consists of measuring the two horizontal components of the electric or telluric field $\left(E_{X}\right.$ and $E_{Y}$ ) and the two horizontal components of the natural magnetic field $\left(H_{X}\right.$ and $\left.H_{Y}\right)$ at the ground surface. After applying the Fourier transform, we obtain for each direction $x$ and $y$, an apparent resistivity sounding, $\rho_{\mathrm{a}}$, as a function of the period $T$, according to [27]

$$
\rho_{a_{i, j}}(T) \approx 0,2 T\left(\frac{E_{i}(T)}{H_{j}(T)}\right)^{2},
$$

where $E_{i}$ is expressed in $\mathrm{mV} / \mathrm{km}$, in nanoTesla and $i$, $j=x y$ or $y x, \rho_{\mathrm{a}}$ in $\Omega \cdot \mathrm{m}, T$ in $\mathrm{s}$, and are the Fourier spectra of the $T$ components. The penetration depth of the method can be evaluated by the skin depth $P$ which is a function of $T$ and the electrical resistivity of the soil which is given by [27]

$$
P=\frac{1}{2 \pi} \sqrt{10 \rho T} \approx 0,5 \sqrt{\rho T},
$$

where $P$ is given in $\mathrm{km}, \rho_{\mathrm{a}}$ in $(\Omega . \mathrm{m})$, and $T$ in $(\mathrm{s})$.

The complete processing of magnetotelluric data consists in calculating the impedance tensor $(Z)$, which correlates for a given frequency $\omega$ the $E$ and $H$ fields [1].

$$
\left(\begin{array}{c}
E_{x}\left(\omega_{x}\right) \\
E_{y}\left(\omega_{y}\right)
\end{array}\right)=\left(\begin{array}{cc}
Z_{x x}\left(\omega_{x}\right) & Z_{x y}\left(\omega_{x}\right) \\
Z_{y x}\left(\omega_{y}\right) & Z_{y y}\left(\omega_{y}\right)
\end{array}\right)\left(\begin{array}{l}
H_{x}\left(\omega_{x}\right) \\
H_{y}\left(\omega_{y}\right)
\end{array}\right) .
$$




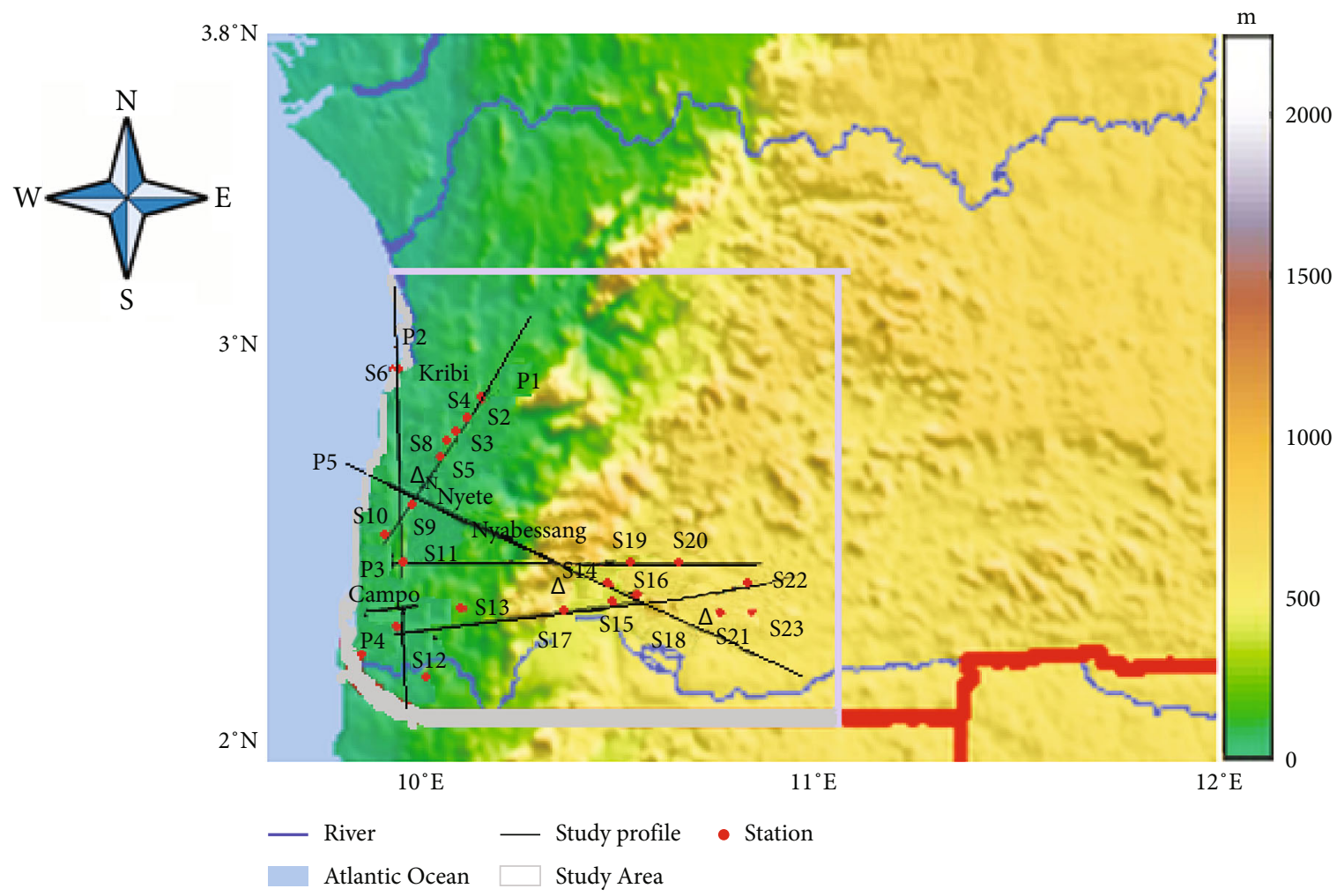

Figure 4: Measurement stations and study profile.

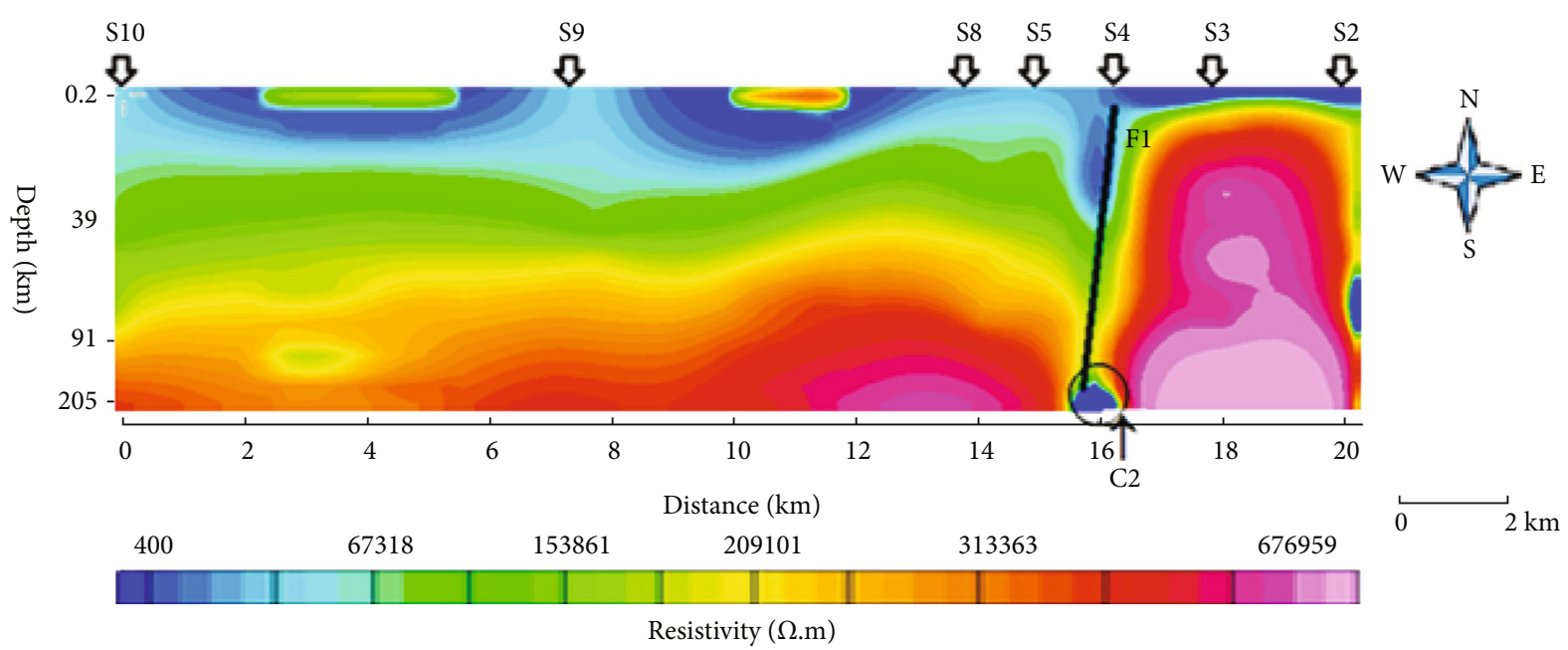

FIgURe 5: 2D resistivity section of profile P1.

In this case, the apparent resistivity is calculated in transversal electric (TE) and transversal magnetic (TM) mode, respectively, as follows:

$$
\begin{gathered}
\rho_{x y}=\rho_{\|}=0.2 \frac{2 \pi}{\omega} Z_{x y}(\bar{\omega})^{2}=0.2 T\left|Z_{\|}\right|^{2}, \\
\rho_{y x}=\rho_{\perp}=0.2 \frac{2 \pi}{\omega} Z_{y x}(\bar{\omega})^{2}=0.2 T\left|Z_{\perp}\right|^{2},
\end{gathered}
$$

$Z_{\|}=Z_{x y}$ is the impedance measured in the structural direction or TE mode.
$Z_{\perp}=Z_{y x}$ is the impedance measured in the direction perpendicular to the structure or TM mode, where $Z_{\|}=E_{x} /$ $H_{y}$ and $Z_{\perp}=E_{y} / H_{x}$.

The $Z$ tensor contains all the information necessary for one-, two-, or three-dimensional interpretations of the depth distribution of electrical resistivity.

3.1.2. Thermal Method. Thermal methods include the direct measurements of temperature and/or heat and thus correlate better with the properties of the geothermal system than other methods. However, as a (near-) surface method, they 


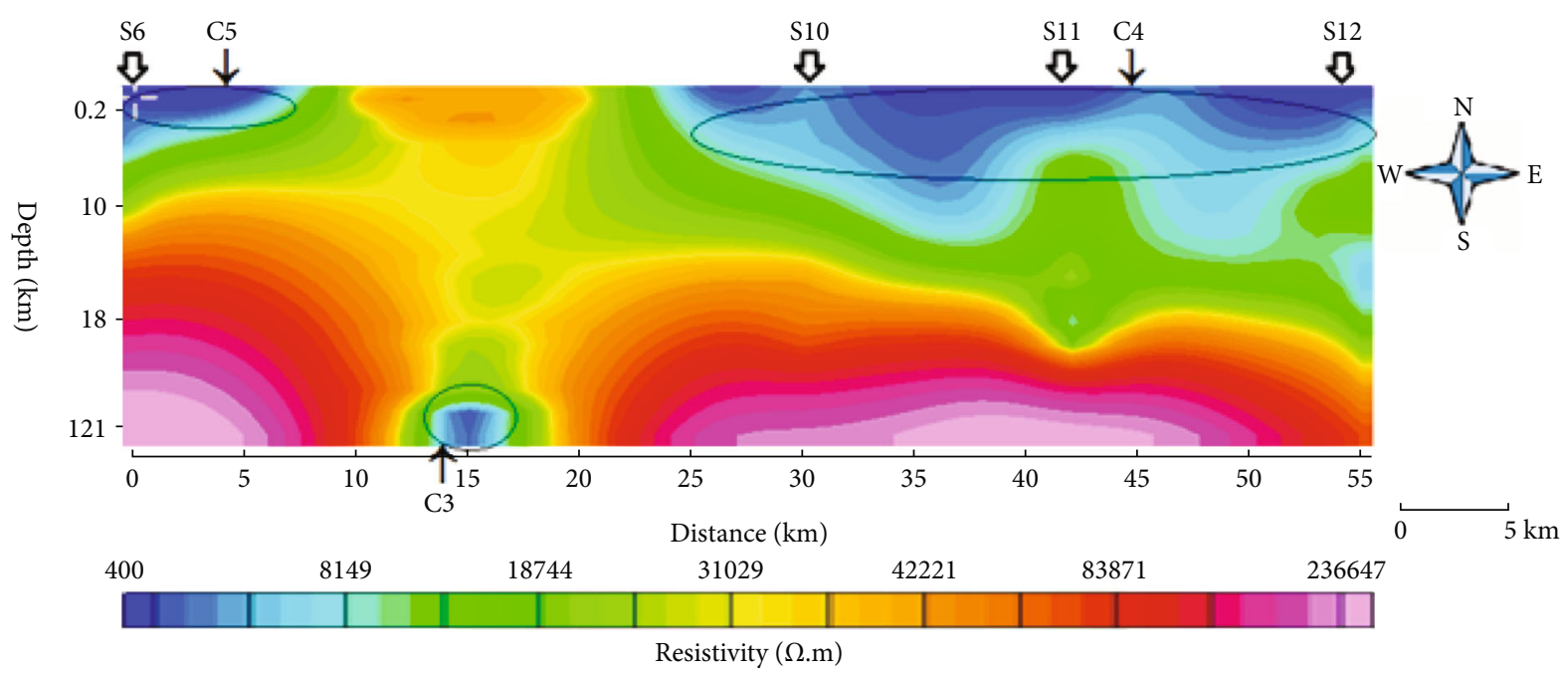

Figure 6: 2D resistivity section of profile P2.

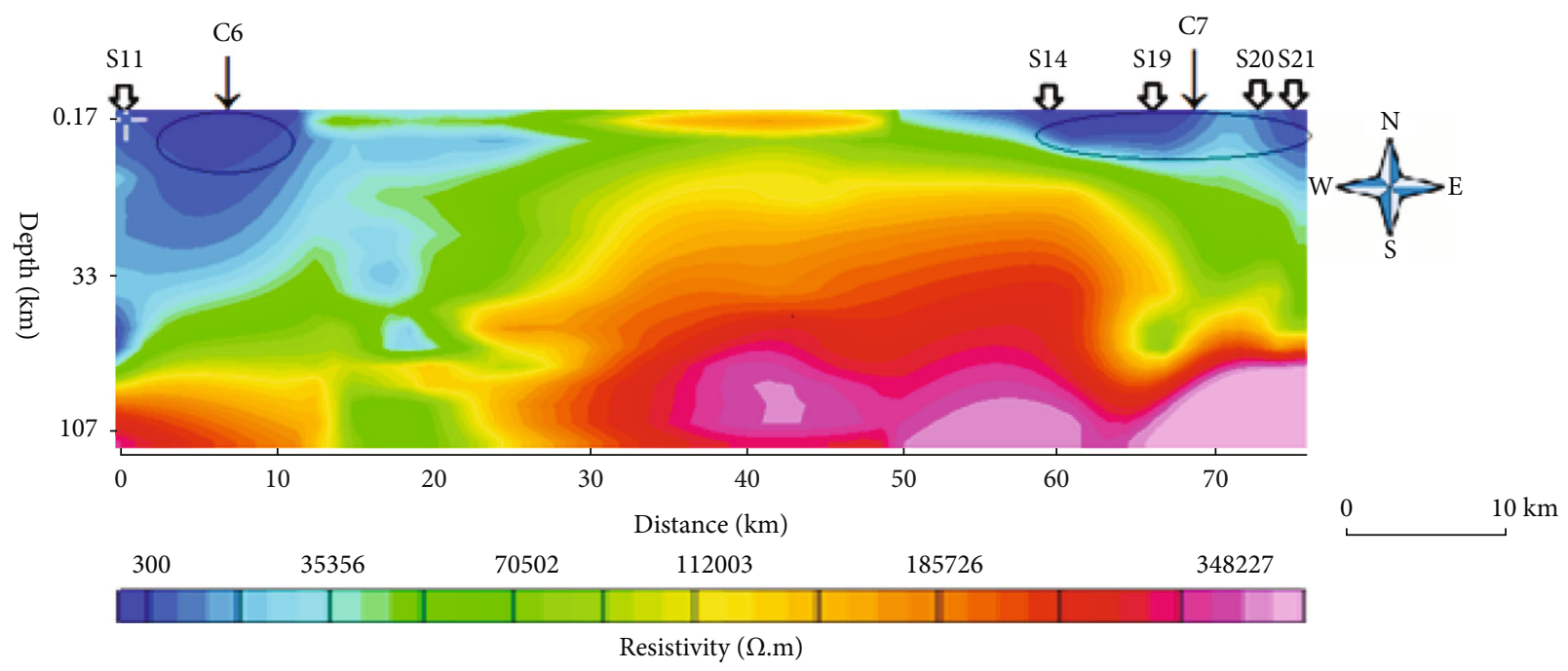

Figure 7: 2D resistivity section of profile P3.

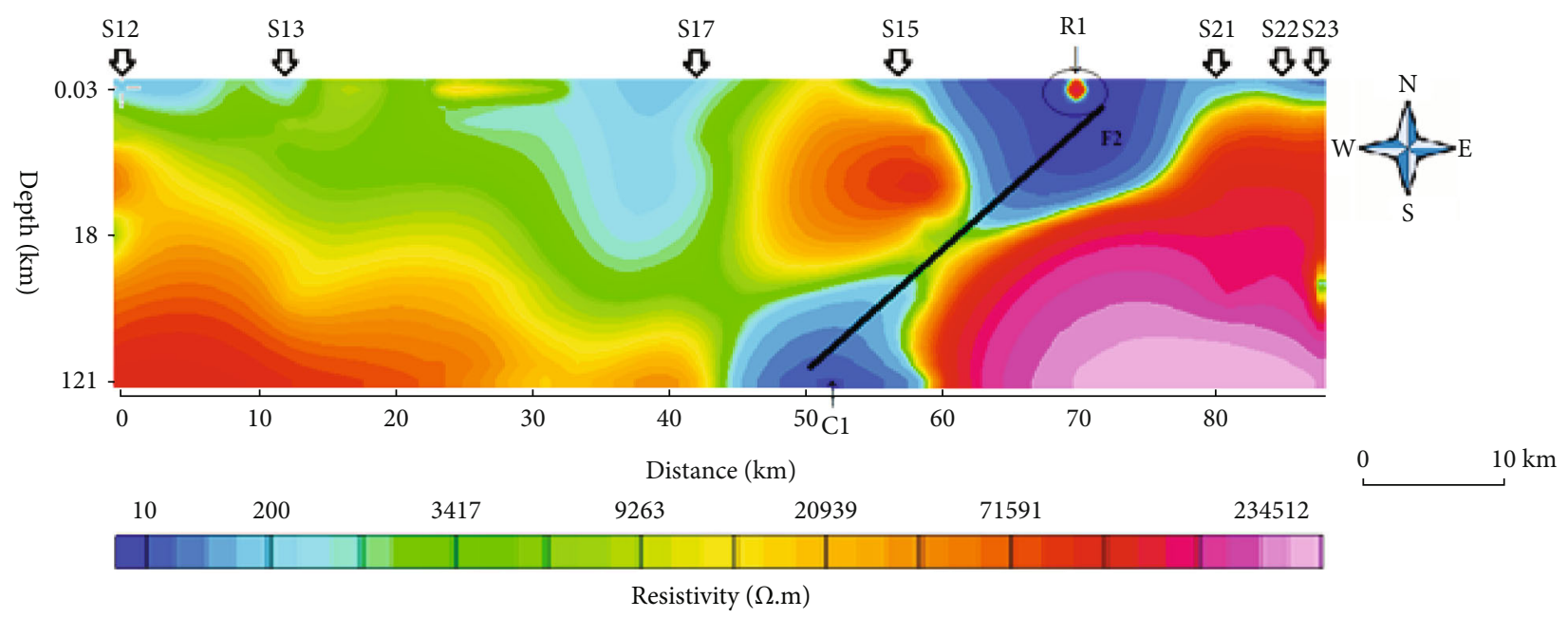

Figure 8: 2D resistivity section of profile P4. 


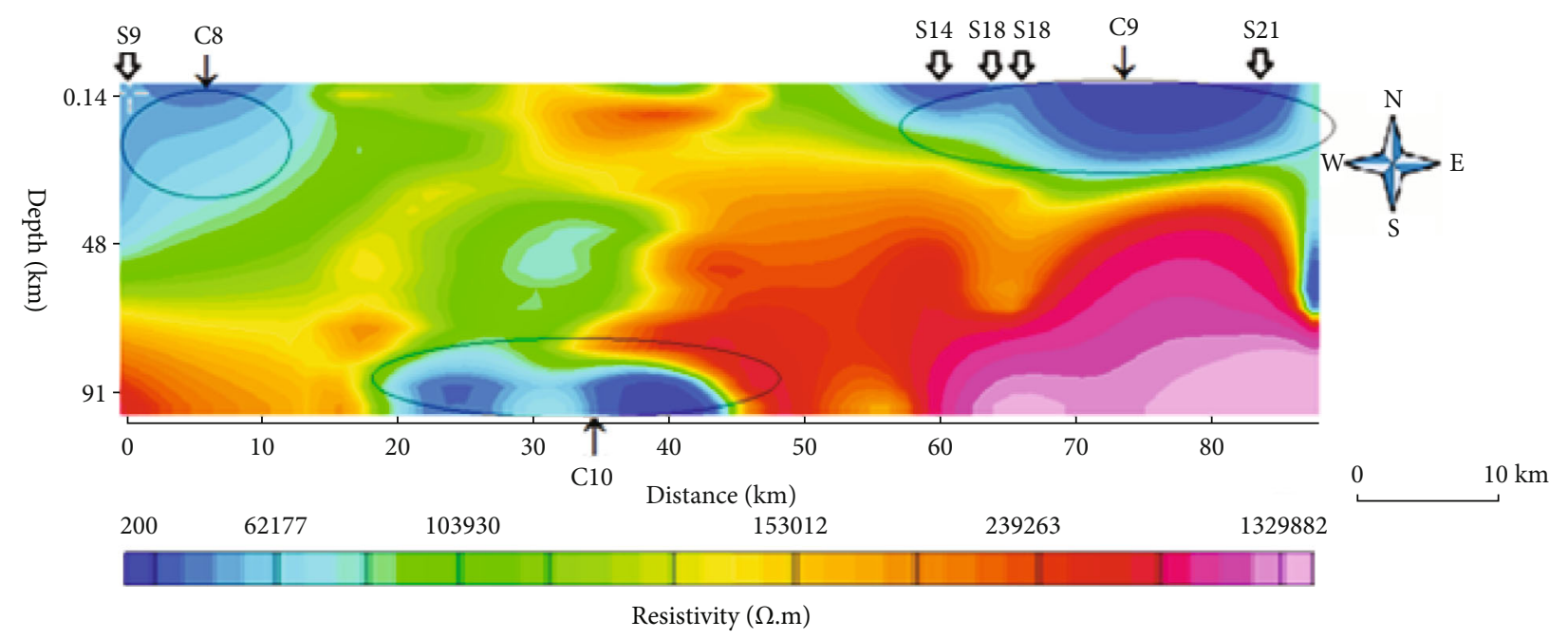

FIGURE 9: 2D resistivity section of profile P5.

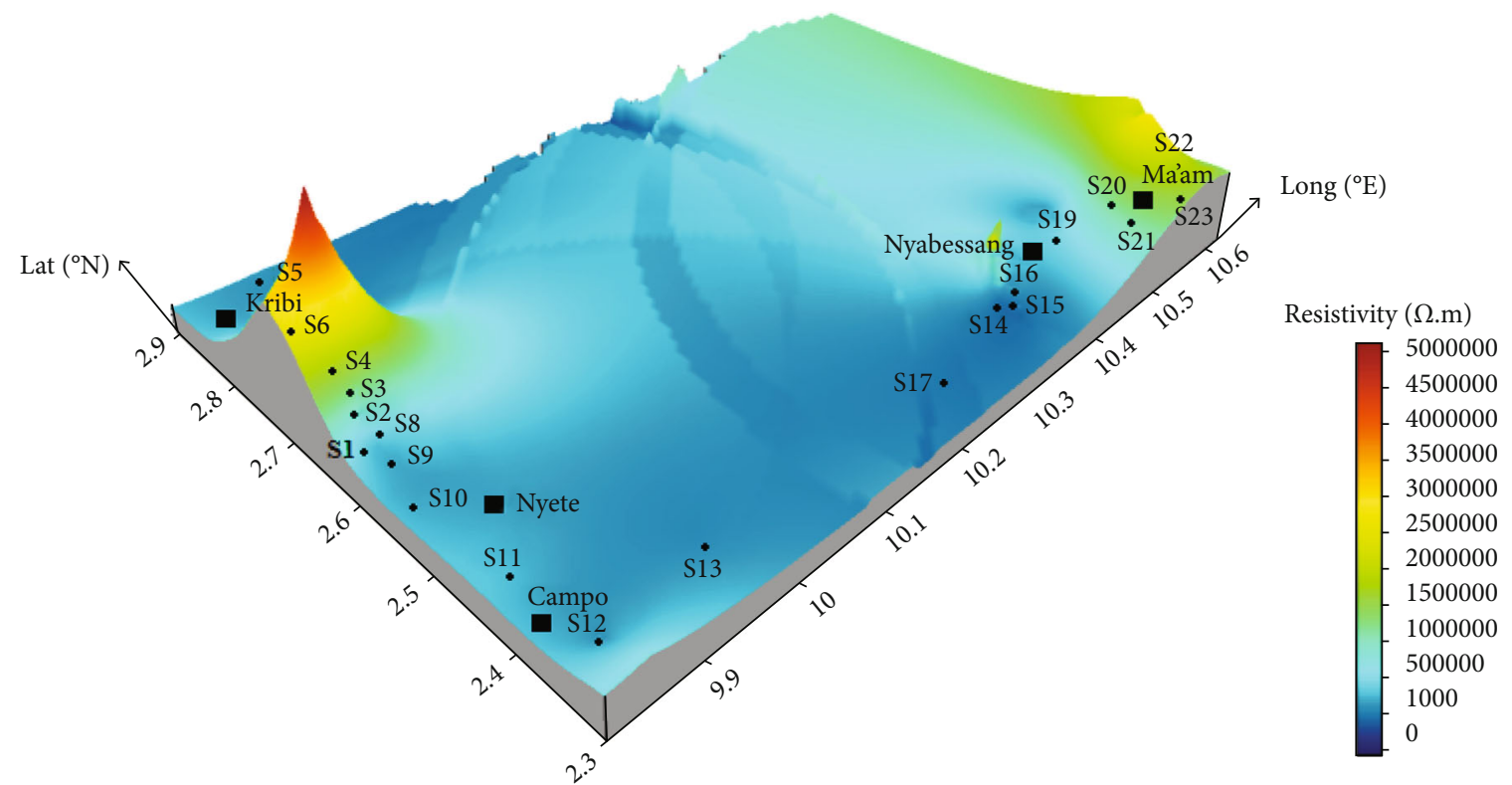

FIgURE 10: 3D model of the resistivity field.

are limited to shallow levels. To measure temperatures close to the surface, in the uppermost meter or so, is fairly simple. Knowledge about status at deeper levels is based on the existence of wells, usually shallow gradient wells (e.g., 30-100 m deep), from which the thermal gradient can be calculated and possibly the depth to the exploitable geothermal resource. Drilling is though usually fairly expensive and puts practical limits to the use of the method. Furthermore, shallow wells are not always adequate to get reliable values on the thermal gradient. The heat exchange mechanism in the earth is important for interpretation of thermal methods. A distinction is made between conduction, which is based on atomic vibrations and is important for transfer of heat in the earth's crust; convection, which transfers heat by motion of mass, e.g., natural circulation of hot water; and radiation, which does not influence geo- thermal systems. The simplified geothermal relationship (5) for thermal conduction is (conductive heat transfer only)

$$
Q_{\text {cond }-z}=-\frac{k \Delta T}{\Delta z}
$$

The parameter $k$, the thermal conductivity $\left(\mathrm{W} / \mathrm{m}^{\circ} \mathrm{C}\right)$, is a material constant, which ranges between 1 and $5 \mathrm{~W} / \mathrm{m}^{\circ} \mathrm{C}$, with the low values usually associated with sedimentary formations and the higher for crystalline rocks. The thermal gradient, $\Delta T / \Delta Z$, gives information on the increase of temperature with depth, and its distribution can be important information for understanding and delineation of the geothermal resource, both on a regional scale and local scale. If the conductive heat transfer, $Q$, is 80 - 


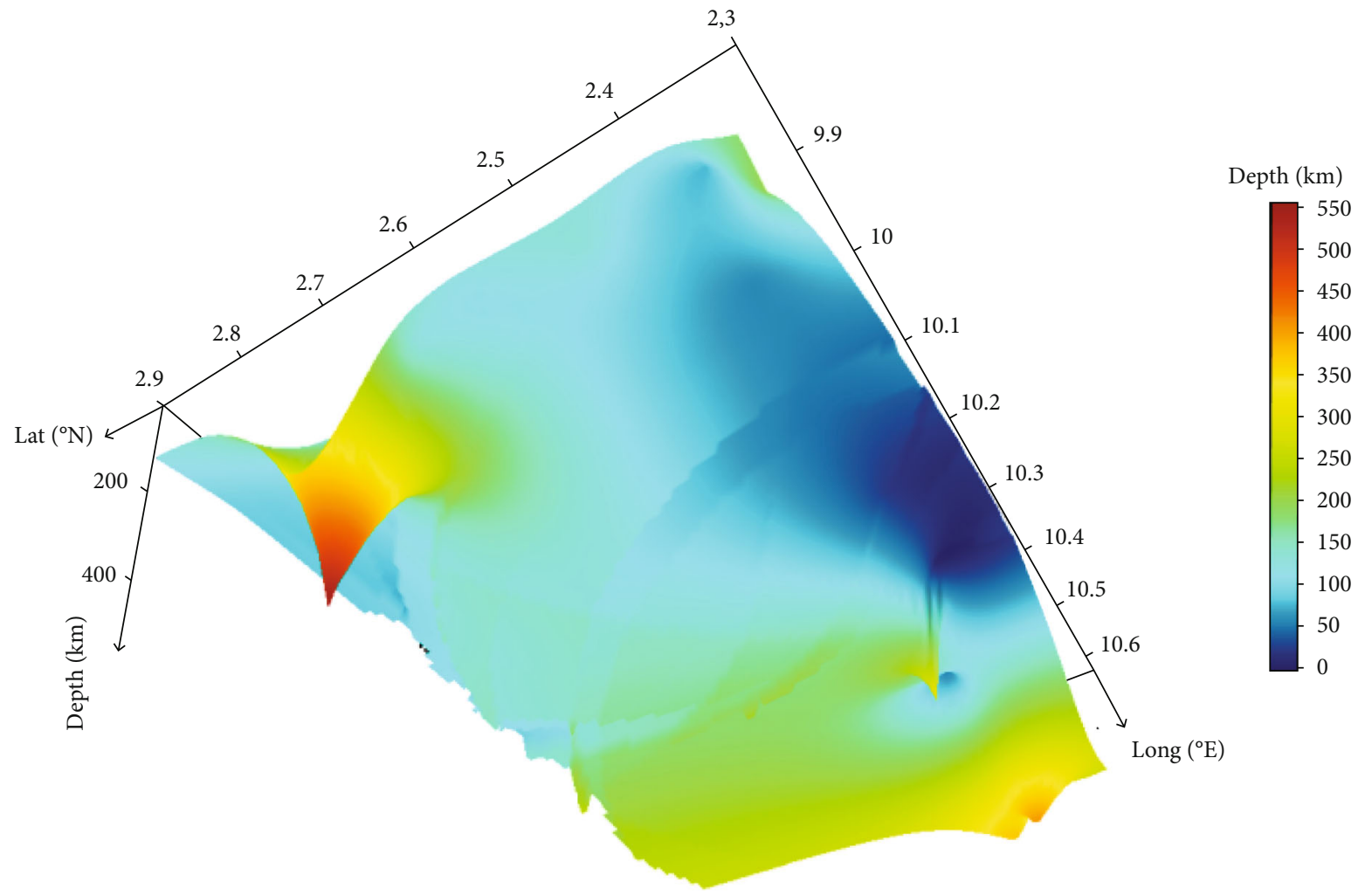

FIGURE 11: Depths of resistivity field structures.

$100 \mathrm{~mW} / \mathrm{m}^{2}$ or higher, it may indicate geothermal conditions in the subsurface. For convection, a distinction is made between free convection, which is driven by density gradients in the fluid (due to a difference in temperature), and thus, the heat is transferred, while forced convection is driven by an external pressure gradient, such as hydrostatic head. Convection is a much more powerful way of transmitting heat but relies on the permeability of the rocks. High-temperature geothermal systems are based on the free convection of the geothermal fluids, while geothermal systems in sedimentary basins are based on conductive heat flow. However, geothermal systems are often of a mixed type. Despite their limitations and their dependence on information from wells, thermal methods are important in geothermal exploration [28].

3.1.3. Landsat 8 Data Processing Methodology. The first step in obtaining the Earth's surface temperature from satellite images is to convert the numerical numbers (DN) into values of spectral radiance in the upper atmosphere using [29]

$$
L_{\lambda}=\mathrm{ML} * Q_{\mathrm{cal}}+\mathrm{AL}-O_{i}
$$

where $L_{\lambda}$ is TOA spectral radiance (Watts $/\left(\mathrm{m}^{2} * \mathrm{sr} * \mu \mathrm{m}\right.$ )), $\mathrm{ML}$ is the radiance multiplicative band $\left(\mathrm{N}^{\circ}.\right), \mathrm{AL}$ is the radiance add band $\left(\mathrm{N}^{\circ}\right.$.), $Q_{\text {cal }}$ is the quantized and calibrated standard product pixel values $(\mathrm{DN})$, and $O_{i}$ is the correction value for band 10 . The second step is to convert top atmosphere (TOA) brightness temperature (BT) by the relation
(7): Spectral radiance data can be converted to top of atmosphere brightness temperature using the thermal constant values in meta data file [30].

$$
\mathrm{BT}=\frac{K_{2}}{\ln \left(K_{1} /\left(L_{\lambda}+1\right)\right)}-273,15, \text {, }
$$

where $\mathrm{BT}$ is the top atmosphere brightness temperature $\left({ }^{\circ} \mathrm{C}\right), K_{1}$ is the constant band $\left(\mathrm{N}^{\circ}\right.$.), and $K_{2}$ is the constant band $\left(\mathrm{N}^{\circ}\right.$.). The third step normalized difference vegetation index (NDVI) [31]. Before calculating the NDVI using Equation (8), the red and near-infrared bands must be corrected for atmospheric effects: Atmospheric effects correct the bands in the visible and near-infrared spectrum. This correction is implemented due to absorption and dispersion processes, the existence of water vapor, gases, and molecules in the atmosphere that affect the amount of radiation received by the sensor. These atmospheric effects are removed in order to obtain a spectral reflection image whose values reflect real physical quantities of the surface.

The red (RED) and near-infrared (NIR) bands have been corrected for atmospheric:

$$
\mathrm{NDVI}=\frac{\mathrm{NIR}-\mathrm{RED}}{\mathrm{NIR}+\mathrm{RED}},
$$

where RED is the DN values from the red band, and NIR is the DN values from the near-infrared band.

The method is called NDVI; it considers three different surface classes, depending on the NDVI values: (a) bare soil 


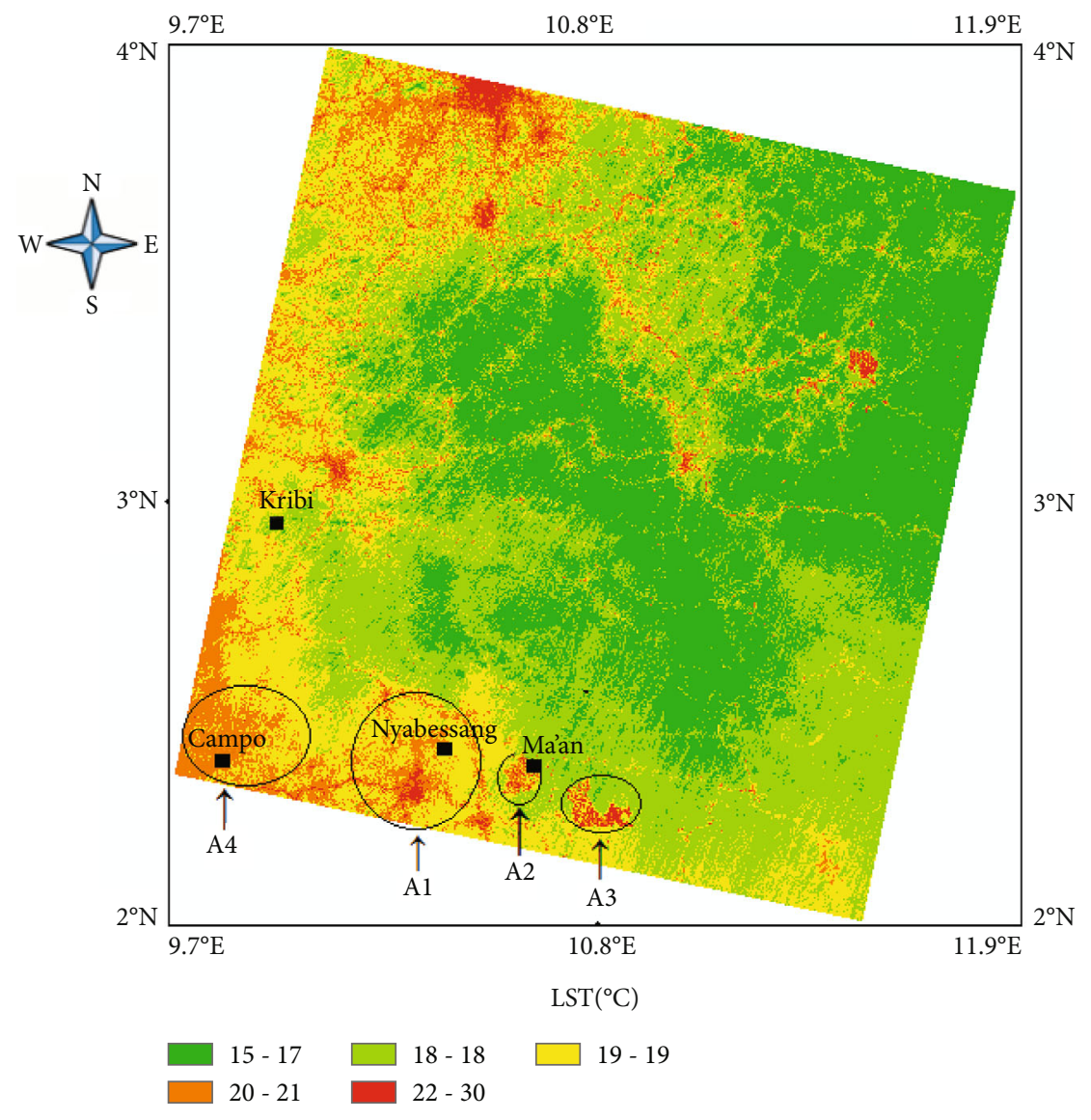

FIGURE 12: LST map of the region.

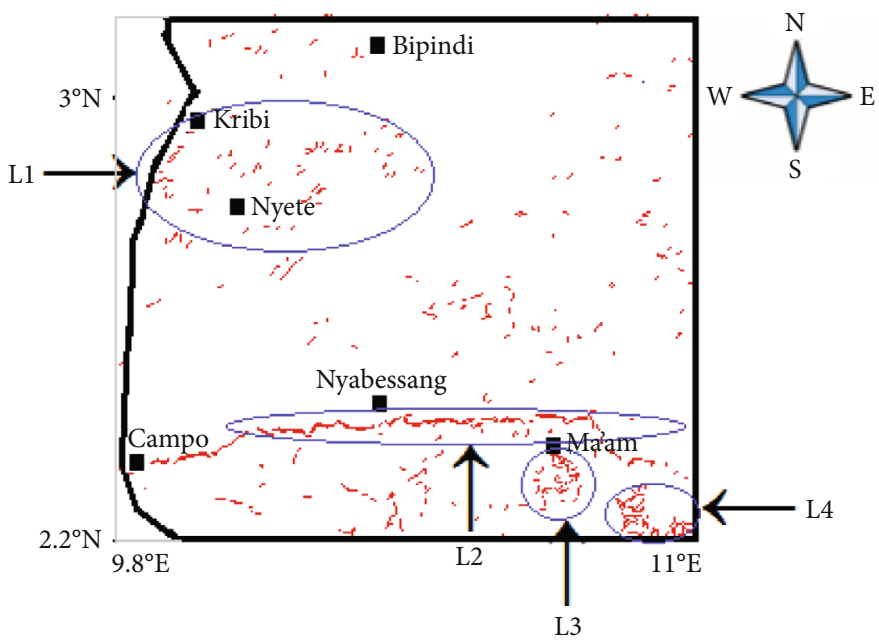

Figure 13: Lineament map of the study area. 


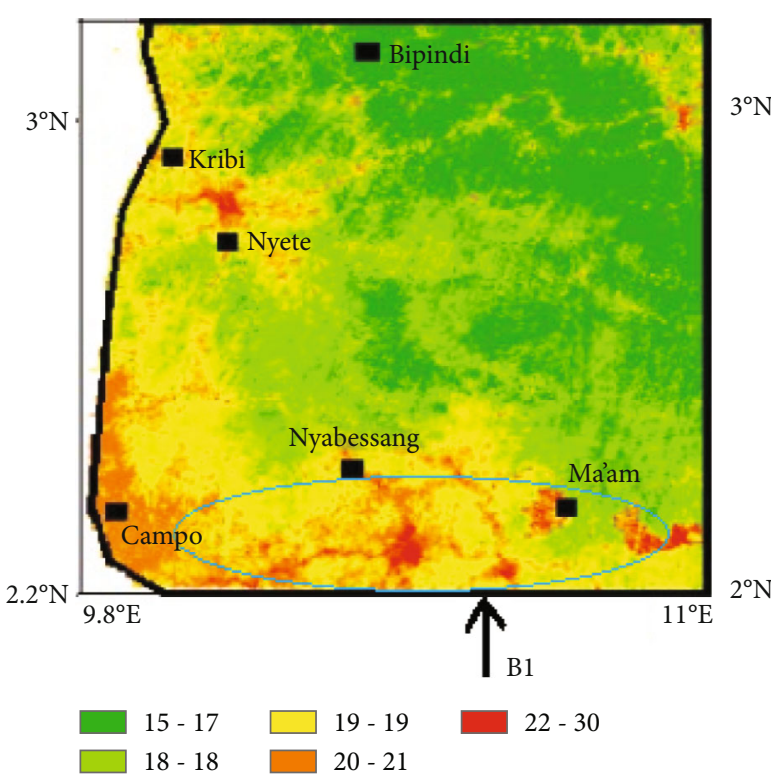

(a)

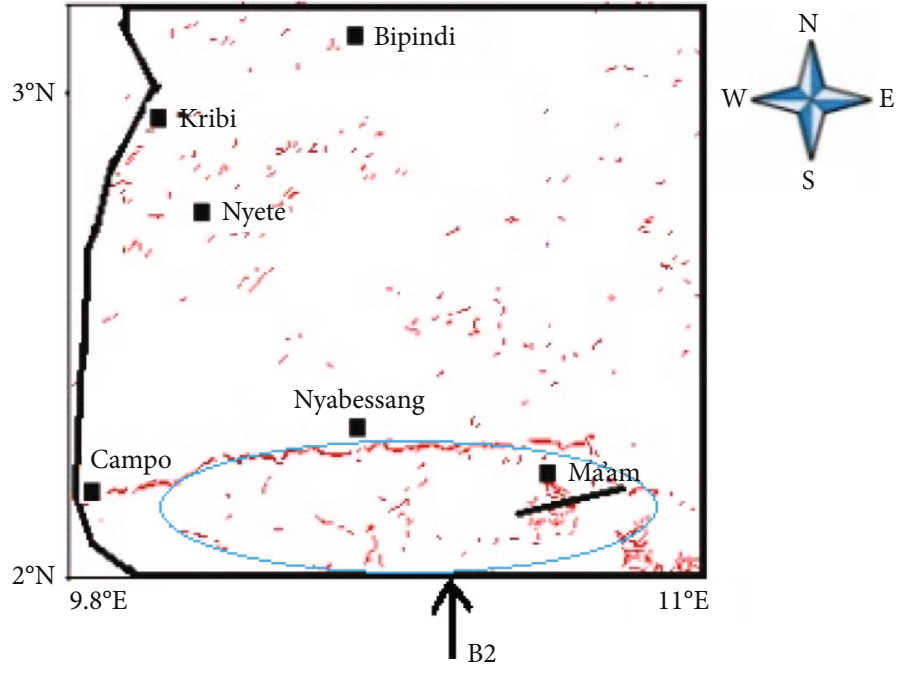

(b)

Figure 14: Comparative map. (a) LST. (b) Lineaments.

(NDVI $<0.2)$, (b) mixed surface $(0.2 \geq \mathrm{NDVI} \leq 0.5)$, and (c) surface entirely covered with vegetation (NDVI $\geq 0.87$ ) [31]. In step four, land surface emissivity (LSE) is calculated. Surface emissivity values are determined using the approach of [31], which consists in determining the emissivity for each pixel based on the proportion of PV vegetation (9), obtained from the normalized differential normalized vegetation index (NDVI) values.

$$
\mathrm{PV}=\left(\frac{\mathrm{NDVI}^{-N D V I} \mathrm{I}_{\text {in }}}{\mathrm{NDVI}_{\max }-\mathrm{NDVI}_{\min }}\right)^{2},
$$

where PV is the proportion of vegetation, NDVI is the $\mathrm{DN}$ values from the NDVI image, $\mathrm{NDVI}_{\min }$ is the minimum DN values from the NDVI image, and $\mathrm{NDVI}_{\max }$ is the maximun DN values from the NDVI image. [31]

Land surface emissivity $(E)$ is calculated by the relation

$$
E=0.004 * \mathrm{PV}+0.986,,
$$

where 0.986 corresponds to a correction value of the equation. Step 5 consists of calculatingthe land surface temperature (LST). The land surface temperature is the radiative temperature which is calculated using TOP of atmosphere brightness temperature, wavelength of emitted radiance, and land surface emissivity. It is calculated by the relation [32]

$$
\mathrm{LST}=\frac{\mathrm{BT}}{\left[1+\left((\lambda * \mathrm{BT}) / C_{2}\right) * \ln (E)\right]},
$$

where $\lambda$ is the wavelength of emitted radiance, $C_{2}=h c / s$; $h$ is Planck's constant, $s$ is the Boltzman constant, and $c$ is the velocity of light.
The steps involved in the complete processing of Landsat data are summarized according to the algorithm proposed by [33] and given in Figure 3.

3.2. Data Acquisition. The data used in this research work come from field campaigns and satellite images.

Surface temperature data from Landsat 8 satellite images are collected over a period of ninety days, and audiomagnetotelluric (AMT) data analyzed for subsurface imagery are collected by the Geoexploration Laboratory of the University of Yaounde 1.

3.2.1. AMT Data. The AMT data analyzed for subsurface imagery were acquired during the geophysical data collection campaign organized by the Geophysics and Geoexploration Laboratory of the University of Yaounde 1 in March 2015 in South Cameroon. It covers an area of $111 \mathrm{~km}^{2}$ on 23 stations regularly spaced with an average step of $4 \mathrm{~km}$ (Figure 4). These resistivity values were collected using a scalar resistivimeter type ECA 540 manufactured at the Geophysical Research Centre of Garchy (France). The stations were chosen so as to be far from any source that could provide a background noise. The resistivimeter uses a frequency ranging from 4.1 to $2300 \mathrm{~Hz}$. The quality or reliability of the data is obtained by suppressing the background noise by performing an average of 3 or more measurements at each station for a given frequency. This eliminates a good proportion of errors in data collection.

In order to have more information on the underground geological structures that can influence resistivity values, it is essential to multiply the study profiles until a data grid is obtained. Therefore, we have defined 5 study profiles on Figure 4: profile $\mathrm{P} 1$ is $20 \mathrm{~km}$ long with 7 irregularly spaced stations (S10, S9, S8, S5, S4, S3, and S2), profile P2 is $55 \mathrm{~km}$ long with 4 stations (S6, S10, S11, and S12), profile P3 is about $70 \mathrm{~km}$ long with 5 stations (S11, S14, S19, S20, 


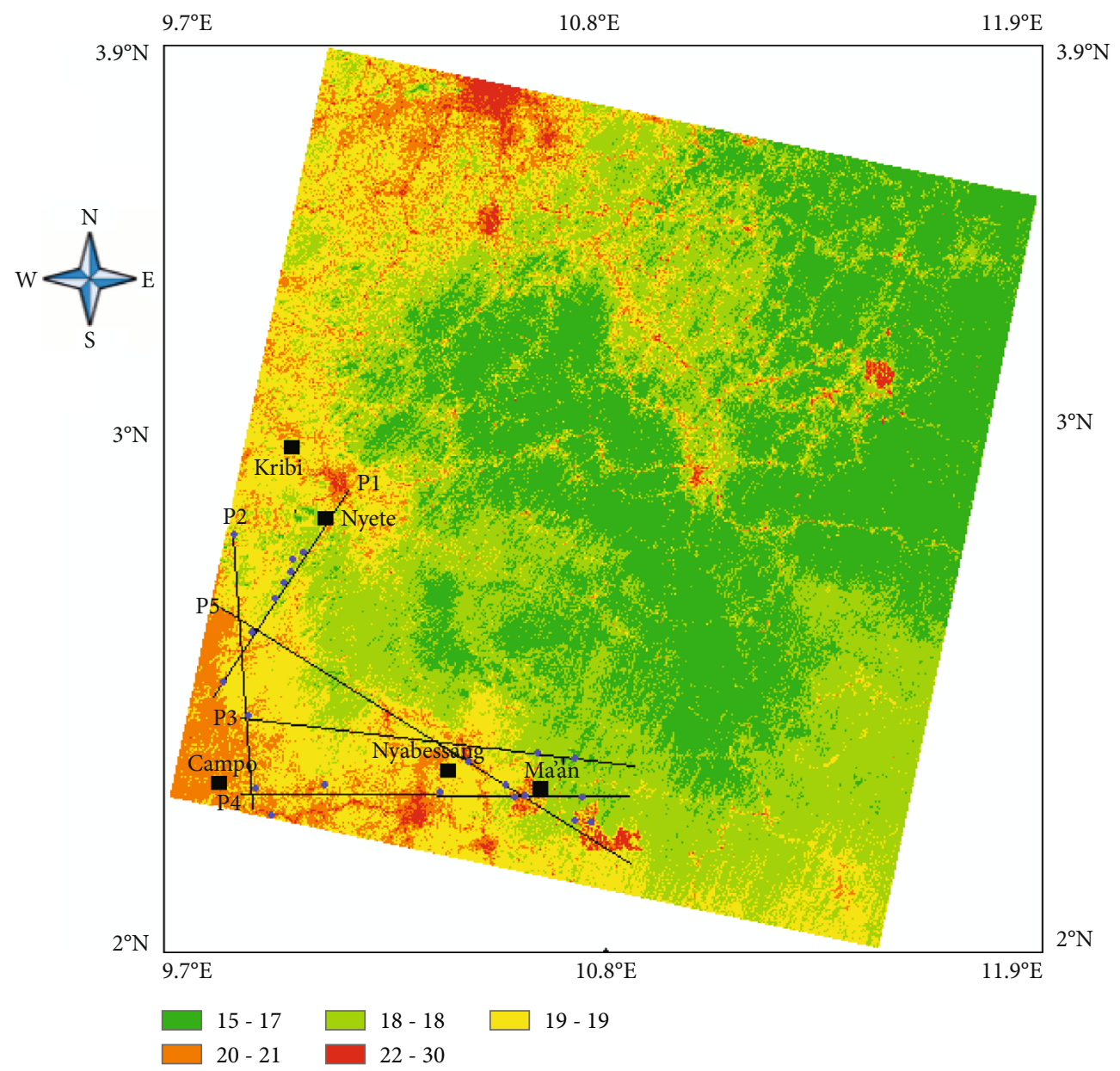

(a)

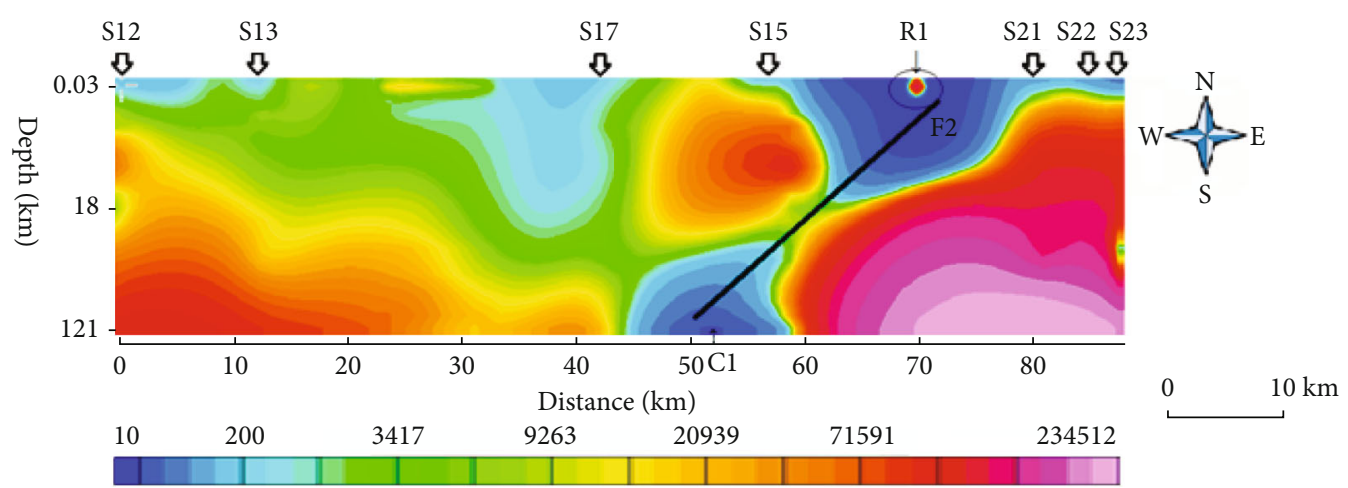

Resistivity ( $\Omega . m)$

(d)

(b)

Figure 15: Continued. 


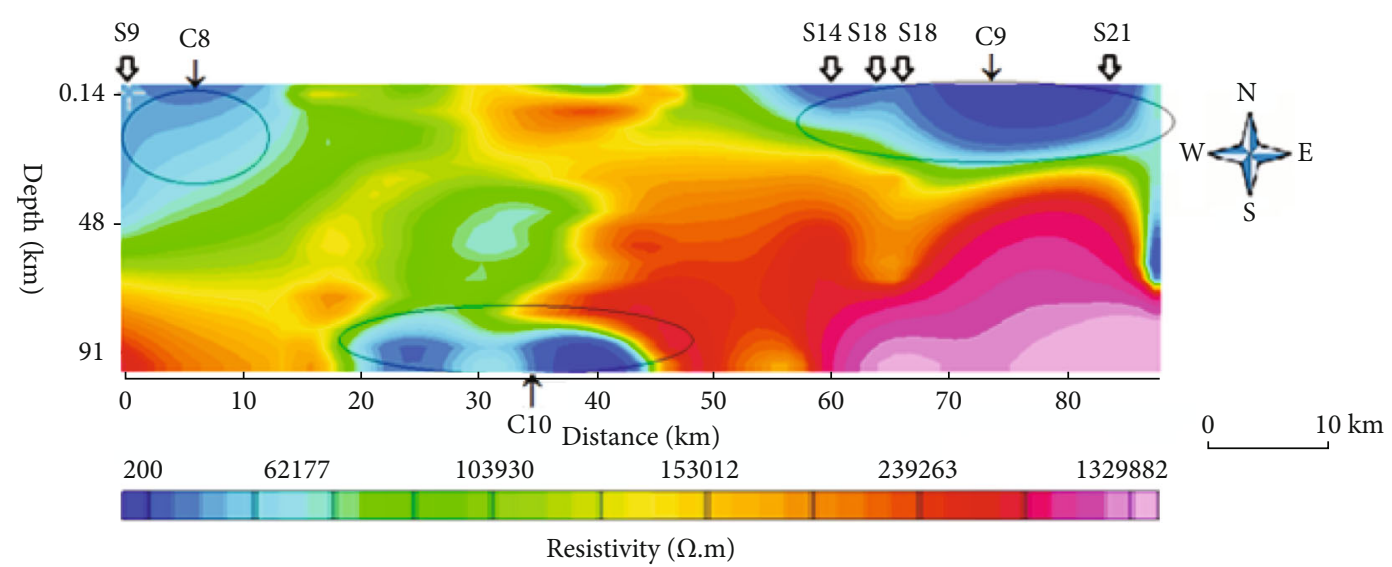

(c)

(c)

Figure 15: (a) Overlay of P4 profile on LST. (b) 2D resistivity section of profile P4. (c) 2D resistivity section of P5 profile.

and S21), profile P4 consisting of 7 stations (S12, S13, S17, S15, S21, S22, and S23) with a length of about $80 \mathrm{~km}$, and profile $\mathrm{P} 5$ with a length of $80 \mathrm{~km}$ and consisting of 5 stations (S9, S14, S16, S18, and S21).

3.3. Landsat 8 Data. The surface temperature data used in this work are extracted from Landsat 8 satellite images. Given the climatic conditions of the study area and its fairly large vegetation cover, the data were selected during the period from January 1st to April 1st, 2015. This is to reduce the influence of clouds in order to have more precision on the data and also for reasons of consistency with the AMT data collection period. Landsat 8 imagery contains $11 \mathrm{spec}-$ tral bands. The physical basis for LST (land surface temperature) recovery is the black body radiation and the Planck function which is used to calculate the radiation emitted by the black body. The earth can be modelled as a black body at a given low temperature $\left(-18^{\circ} \mathrm{C}\right)$. The inverse of the Planck function consists in deriving the luminosity temperature of an object. The sensor acquires the radiation information and stores it in (DN) between 0 and 255. Thus, the surface temperature can be retrieved by converting the values in the (DN) format into degrees Kelvin or Celsius. The PCI geomatics software and ArcGIS 10.1 were used for a complete the data analysis.

\section{Results and Discussion}

4.1. 2D Resistivity Section of Profiles. The pseudosection shows the resistivity variations along a vertical section. It allows to highlight the areas of lateral discontinuities [34] which appear with a strong horizontal resistivity gradient and therefore contrast with tabular areas where the isoresistivity lines are horizontal. This is obtained by plotting interstation distances on the $x$-axis and the logarithms of frequencies or pseudodepths on the $y$-axis. Finally, the isoresistivities are plotted; the corresponding resistivity can be plotted on each curve. The pseudosections are therefore lines of isoresistivities drawn along a given measurement profile and covering a frequency range.

The potential zones for geothermal exploitation are between $1 \Omega \cdot \mathrm{m}$ and $55 \Omega \cdot \mathrm{m}$ and are fed at depth by volcanic rocks [2]. The geothermal system can therefore be brought to the surface by convection or conduction.

4.1.1. Profile P1. Figure 5 shows the $2 \mathrm{D}$ resistivity section of the P1 profile-oriented NE-SW. A high resistivity value is observed in the locality of Lolabé (S2) and the Kribi Deep Water Port (S3). This shows that this structure stands on the stable resistant socle. On the other hand, it can also be observed at a depth of about $1.5 \mathrm{~km}\left(C_{2}\right)$, a decrease in resistivity values $(<300 \Omega \cdot \mathrm{m})$ pointing here a terrain that may be altered and favorable to fluid circulation [1,35]. It can be geometrically justified as the extension of the Kribi fault F2 at depth (Figure 4).

4.1.2. Profile P2. Figure 6 shows the P2 profile which is N-S oriented and extends from Bongahele (S6) to Mvass (S12) over a length of $55 \mathrm{~km}$. We generally observe a decrease in resistivity values $(<500 \Omega \cdot \mathrm{m})$ for surface formations $\mathrm{C} 4$ and C5: This may be due to sedimentary deposits consisting of the less resistant rocks that abound in the Kribi-Campo sedimentary subbasin. A deep formation is observed at C3, less resistant, and located in a very resistant surrounding. This zone could represent the roof of the sedimentary formations [15]. The range of variation in resistivity values of this C3 anomaly suggests the presence of a highly viscous fluid cluster that could probably be a hydrocarbon reservoir. The resistivity values observed in block C3 (200-400 $\Omega \cdot \mathrm{m})$ are higher than the range of $1-55 \Omega \cdot \mathrm{m}$ acceptable to justify the presence of a geothermal reservoir on volcanic soil $[2,35]$.

4.1.3. Profile P3. Figure 7 shows the P2 profile in West to East orientation. A considerable increase in resistivity values was observed as we move from high to low frequencies. All the stations lie nearly subsurface on a less resistant substratum varying from 300 to $500 \Omega \cdot \mathrm{m}$ (C6 and C7) and in depth on the very resistant base. This result interpreted as the 

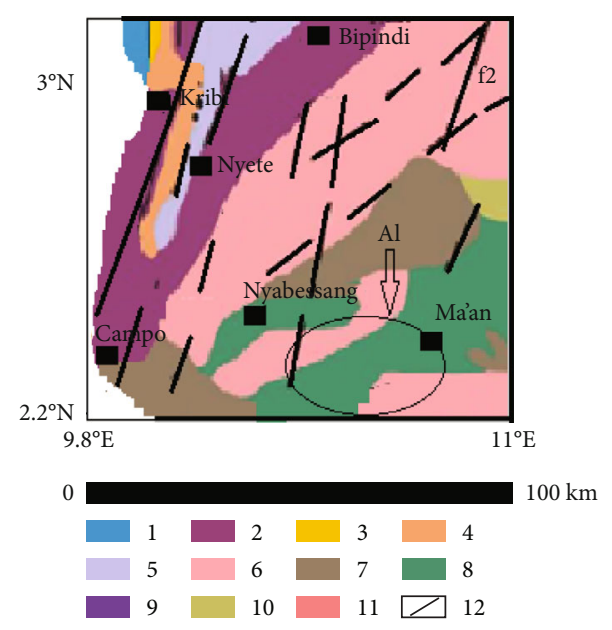

(a)

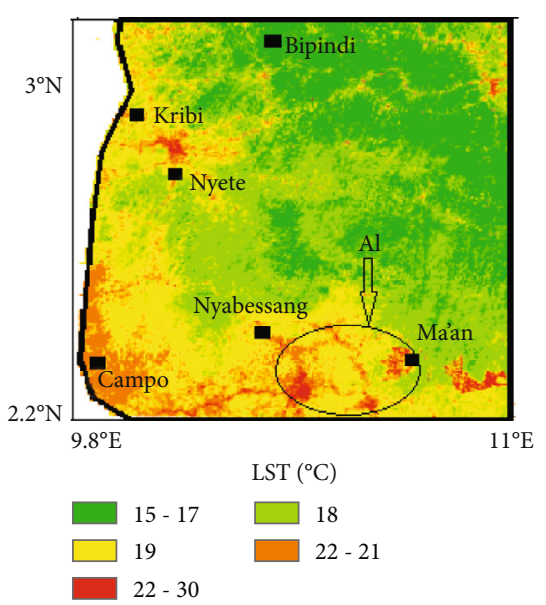

(b)

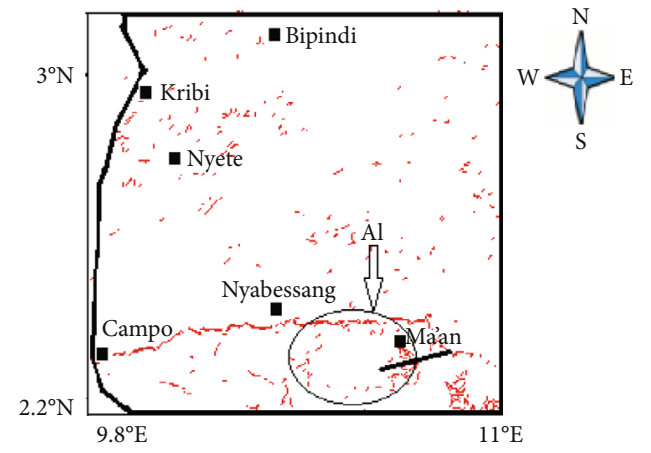

(c)

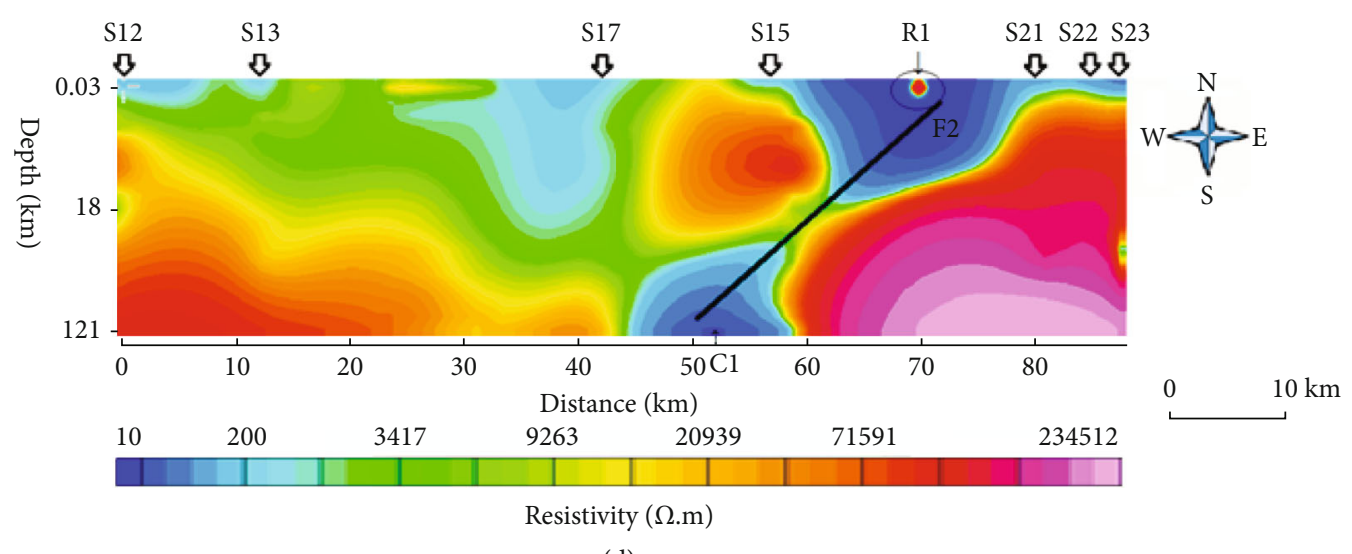

(d)

(d)

Figure 16: Correlative map. (a) Geological maps. (b) LST. (c) Lineaments. (d) Resistivity values.

transition of the Pan-African belt to the cratonic zone. The drop in resistivity values observed in C6 and C7 could represent a superficial sign of an outcrop of sediments.

4.1.4. Profile P4. Figure 8 shows the $\mathrm{W}$-E-oriented 2D resistivity section of the profile $\mathrm{P} 4$, a low subsurface between stations S15 and S21. This increase with depth in the localities of Alen, Ma'an, and Bitoto (S21, S22, and S23). On the other hand, the opposite phenomenon is shown up in the vicinity of Menve'ele; this locality lies on a fairly resistant soil near the surface and on a strongly altered ground at depth. The low observed in $\mathrm{C} 1$ materializes a deep and highly conductive zone $(<15 \Omega \cdot \mathrm{m})$ that could represent the roof of a source of warm saline fluid [36]. The C1 zone could represent a geothermal reservoir located at $1300 \mathrm{~m}$ depth. The Ntem river would be fed at depth by this more or less hot source through the F2 fault-oriented NE-SW. Between stations S15 and S21, there is a very resistive anomaly bringing out the presence of a very resistant intrusive body on the surface.

4.1.5. Profile P5. The 2D resistivity section of the P5 profile shown in Figure 9 is NW-SE oriented. A general observation 


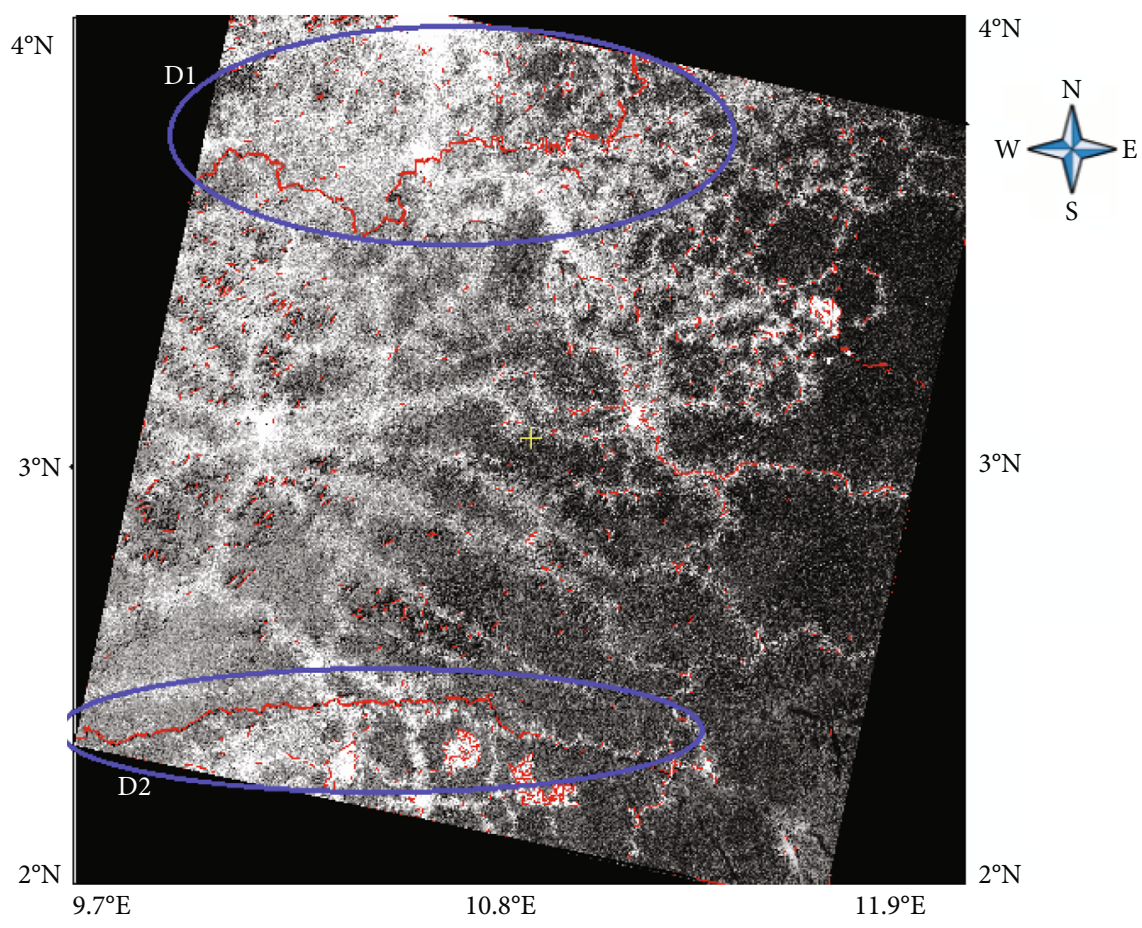

FIGURE 17: Regional lineament map of the study area.

shows three main areas of low resistivity $(150-1000 \Omega \cdot \mathrm{m})$. The surface zones C8 and C9 located in the localities of Alen, Menve'ele tribune, Ebodje, and the deep zone C10. The surface zones C8 and C9 could reflect some outcrops of muddy pools or sediment deposit. The deep C10 zone at depth signifies an accumulation of sediments in the form of mud and prompts a search for economic interests.

\subsubsection{D Resistivity Model of the Resistivity Field and Depth} of Structures. In order to have a good view of the resistivity variations in the study area, a 3D model of the resistivity field was produced (Figure 10) as well as the associated depth map (Figure 11). In the Kribi locality, a peak (P1) of resistivity of approximately $10^{6} \Omega \cdot \mathrm{m}$ is observed at a depth of about $500 \mathrm{~km}$. This justifies the stability of the bedrock and the construction of some structures such as the deepwater port of Kribi. Low resistivity values $(<15 \Omega \cdot \mathrm{m})$ are visible in the P2 zone at estimated depths of $5 \mathrm{~km}$. This deep conductive zone highlighted on the $\mathrm{P} 4$ resistivity profile could indicate a heat source, which findings are in agreement with the works of $[13,37]$.

4.2. Land Surface Temperature Anomalies. Figure 12 shows the land surface temperature (LST) map for the study area obtained with ArcGis software. The range of surface temperature values is between 15 and $30^{\circ} \mathrm{C}$. Taking into account the greenhouse effect, the average temperature at the earth's surface is $15^{\circ} \mathrm{C}$. This value is considered the reference temperature (the range of $1-55 \Omega \cdot \mathrm{m}$ is the range to justify the presence of a geothermal source [2]). The temperature anomaly is defined as the difference between the temperature at a given point and the reference temperature. The observation of this map enables to categorize the LST values in three large ranges: from $15^{\circ} \mathrm{C}$ to $18^{\circ} \mathrm{C}$, from $19^{\circ} \mathrm{C}$ to $21^{\circ} \mathrm{C}$, and from $22^{\circ} \mathrm{C}$ to $30^{\circ} \mathrm{C}$. According to the work of [12], the geothermal temperature anomalies are between $19.35^{\circ}$ and $37.00^{\circ} \mathrm{C}$. The A1, A2, A3, and A4 zones can therefore be identified as geothermal anomaly zones. Satellite thermal anomalies reflect excess heat from the interior of the earth [9]. Despite the hypothesis that these zones could be the site of interaction between solar radiation and the heat from the interior of the Earth, this observation can reflect the permanent contact between the Congo craton and the Pan-African belt which causes friction and releases internal heat. Understanding the surface energy balance and underground heat transfer facilitates the detection of geothermal regions [9]. In geothermally active areas, the surface temperatures obtained come from solar heating i.e., from the earth's interior. This observed positive temperature anomaly could result in surface or deep-water heating [12]. Zones A1, A2, A3, and A4 are favorable and indicative for the identification of geothermal sources.

4.3. Structure Lineament Map. Figure 13 shows the map of minor lineaments obtained using PCI geomatica 12 software. On this map, areas with high lineament densities in the localities of Ma'an and Nyabessang (L2, L3, and L4) moderately densified areas such as around Kribi and Nyete (L1) and nondensified areas. These lineaments are mainly oriented E-W towards the Atlantic Ocean and hydrographically materialize the direction of water flow. The long thread of lineaments observed in L2 draws the bed of the Ntem river which flows towards the sea. One of the clues indicating the presence of a geothermal field is the frequency of 
lineament structures [12]. Thus, the dense structure of lineaments observed in the localities of Ma'an and Nyabessang (L3 and L4) could hide the presence of a potential geothermal zone.

4.4. Spatial Correlation between LSF Anomalies and Lineaments. Figure 14 shows a comparative map of the thermal anomaly zones in (a) and the lineament map in (b). The temperature anomaly zones correlate with fault development [9]. Observation of the two maps shows that the spatial correlation between temperature and lineament anomalies for zones B1 and B2 is much stronger. This is consistent with the works of [9]. This may be due to the fact that the shallow sediment deposition zone has a better heat transfer efficiency.

4.5. Spatial Correlation between LST Anomalies and Resistivity Values. The geothermal regions have a temperature anomaly ranging from 19.35 to $37.00^{\circ} \mathrm{C}$ and low resistivity values below $7 \Omega \cdot \mathrm{m}$ [12]. Comparing the $2 \mathrm{D}$ resistivity section of profile 4 in Figure 15(b) to the LST values in Figure 15(a), the low resistivity zones S15, S21, S22, and S23 generally coincide at high temperatures $\left(22^{\circ} \mathrm{C}-30^{\circ} \mathrm{C}\right)$. Indeed, underground resistivity is affected by the combined effects of temperature, pressure, mineral composition, and geological structures [38]. Generally, an increase in temperature and in the proportion of highly conductive minerals in the rock will lead to a decrease in resistivity. A resistivity anomaly reflects possible areas of accumulation of geothermal fluids because these fluids have physical and chemical properties characterized by temperature and salinity that produce very high conductivities [36]. Since the dominant geological formations in this part are of sedimentary and metamorphic origin, the highly conductive zone C1 (Figure 15(b)) estimated at a depth of $1300 \mathrm{~m}$ could represent the roof of a fairly large geothermal reservoir.

The same observation is made with the $2 \mathrm{D}$ resistivity section of profile P5 (Figure 15(c)) where stations S9, S14, $\mathrm{S} 16, \mathrm{~S} 18$, and S21 are located on the less resistive zones $(<$ $200 \Omega \cdot \mathrm{m})$. Despite this decrease in resistivity values, the presence of a geothermal field cannot be asserted here with certainty, since these resistivity values are still considerably higher than the acceptable value of $15 \Omega \cdot \mathrm{m}$, included in the range of $1-55 \Omega \cdot \mathrm{m}$, which is the range to justify the presence of a geothermal source [2].

4.6. Spatial Correlation between Geological Maps 16(a), LST 16(b), Lineaments 16(c), and Resistivity Values 16(d). Figure 16 shows the geological maps 16(a), surface temperatures 16(b), lineaments 16(c), and resistivity 16(d). Geothermal reservoirs in active volcanic zones or thermal anomalies are located in a linear pattern according to fault lineaments [39-40]. The geothermal system of Paipa (Colombia) is different because the geothermal reservoirs are located through sedimentary rocks, which justifies a lateral distribution of hot fluids [12]. The location of thermal anomalies is mainly in the A1 zone. This localization would be produced by the friction between two plates which would raise the temperature of the fluid at a certain depth, whose circulation is facilitated by the F2 fault which functions as a migration path.

4.7. Discussion. Figure 17 shows the regional lineament map of the study area obtained after filtering and processing of satellite image data of the study area. The observation of this map highlights the faults enabling the circulation of fluids: indeed, the lineaments juxtaposed in blocks D1 and D2 materialize, respectively, the Sanaga and Ntem rivers in the field. These rivers flow from East to West towards the Atlantic Ocean. This good correlation of the information obtained from this lineament map with that observed in the field led to the conclusion that the satellite images were collected with a good spatial resolution and a good accuracy. According to [41], the value of the normalized vegetation index is greater than 0.87 (NDVI > 0.87) if the ground is covered with vegetation, and the mean emissivity value is equal to 0.99 $(E=0.99)$. In this work, the maximum value of $\mathrm{NDVI}=1$ and the emissivity $0.986<E<0.99$ confirm that our study area is strongly covered with vegetation. The emissivity value found is in agreement with the results obtained by [41]. The range of resistivity values in zone $\mathrm{C} 1$ is $100 ; 0 \Omega \cdot \mathrm{m}$ (Figure 16(d)). This two-dimensional model of resistivity is valid and correlates with that found by the following authors: [42] which shows a good conductive region (< $10 \Omega . \mathrm{m}) ;$ [43] validates a lens-shaped conductor of thickness between $300 \mathrm{~m}$ and $500 \mathrm{~m}$ covering a zone of low resistivity $(10 \Omega \cdot \mathrm{m}$ to $60 \Omega \cdot \mathrm{m})$; it is the same for the work of $[44,45]$ which characterizes geothermal reservoirs by the low resistivity values. [2, 36] also obtained resistivity values for conductive zones, respectively, between $[1-55[\Omega \cdot \mathrm{m}$ and $17.3 \Omega \cdot \mathrm{m}$. The work of [8] supports the idea that the temperature anomaly zones are superimposed on the lineaments.

\section{Conclusion}

This study combines AMT and Landsat 8 data with the aim of carrying out a geothermal prospecting in South Cameroon. The surface temperature data was extracted from NASA Landsat 8 satellite images with a spatial resolution of $15 \mathrm{~m}$. The processing of these data using PCI geomatica software enabled to identify the 5 zones of thermal anomalies (A1, A2, A3, A4, and A5) in Figure 9 with a difference of 5 to $10^{\circ} \mathrm{C}$ above the average temperature. Among these anomalies, the choice of $\mathrm{A} 1$ as a geothermal anomaly zone (Figure 12) is validated by a double spatial correlation: the first being the areas identified as zones of weak resistive anomaly, and the second areas favorable to the development of lineaments. From this work, it results that the remote sensing method is a valuable tool for the detection of thermal anomalies with profitability and precision in the recovery of the surface temperature. Remote sensing is a rapid means in the mapping, exploration, and assessment of geothermal resource. Despite these yields in addition to the results which are spatially representative at regional scales, remote sensing is not expected to suffice as the sole tool in the exploration and monitoring of geothermal resources. Conventional in situ data collection methods and the 
integration of the geothermal mechanism with the correlation of geological features have significantly improved the applicability of geothermal sensing using remote sensing.

\section{Data Availability}

The data used in this work were collected by a team from the Geophysics and Geoexploration Laboratory of the University of Yaoundé 1 under license and cannot be made freely available. Requests for access to these data should be addressed to Owona Angue Marie Louise-Clotilde (mlasseowona@yahoo.fr).

\section{Conflicts of Interest}

The authors declare that there are no conflicts of interest regarding the publication of this article.

\section{Authors' Contributions}

Piameu Kwagag Joel provided the LST analysis and 2-D resistivity sections and participated in the writing, interpretation, and presentation of the results. Owona Angue Marie Louise-Clotilde coordinated the work and contributed in the analysis of lineament maps and correlation to resistivity values. Ngatchou Evariste contributed to the PCI geomatica and Arcgis software analysis. Njinti-Nfor justified and defined the different resistivity study profiles between stations. Kue Petou Rokis Malquaire contributed in the interpretation of the results and in the writing of the manuscript. Njandjock Nouck Philippe supervised and made an in-depth contribution on the correlation between the resistivity values, LST, lineaments, and geological framework necessary and sufficient to characterize the geothermal reservoirs.

\section{Acknowledgments}

We are grateful to the University of Yaounde for funding this study.

\section{References}

[1] H. Fabriol, A. Bitri, B. Bourgeois, N. Debeglia, and A. Genter, "Geophysical methods applied to the assessment of the Bouillante geothermal field (Guadeloupe, French west indies)," in World Geothermal Congress 2005, pp. 24-29, Antalya, Turkey, 2005.

[2] H. Fabriol, N. Debeglia, and J. Baltassat, "Geophysical methods applied to geothermal exploration in a volcanic island context," Bibliographic synthesis. Final report. BRGN/RP-53137EN, 112 p., 43 illustrations, 5 tables, 1 directory.

[3] B. A. Cherkose and H. Saibi, "Investigation of the Ayrobera geothermal field using 3D magnetotelluric data inversion, Afar depression, NE Ethiopia," Geothermics, vol. 94, 2021.

[4] C. T. Tabod, Seismological studies of the Cameroon volcanic line, in West Africa, [Ph.D. thesis], University of Leeds, United Kingdom, 1991.

[5] B. Ateba, N. Ntepe, G. E. Ekodeck, D. Soba, and J. D. Fairhead, "The recent earthquakes of South Cameroon and their possible relationship with main geological features of Central Africa," Journal of African Earth Sciences, vol. 14, no. 3, pp. 365-369, 1992.

[6] N. Ntepe, A. F. Tongwa, U. R. Ubangoh, B. Ateba, J. Nnange, and J. V. Hell, "The July 2002 earthquake in the Kribi region: geological context and a preliminary evaluation of seismic risk in southwestern Cameroon," Journal of African Earth Sciences, vol. 40, no. 3-4, pp. 163-172, 2004.

[7] V. Ngako, P. Affaton, J. M. Nnange, and T. Njanko, "Pan-African tectonic evolution in central and southern Cameroon: transpression and transtension during sinistral shear movements," Journal of African Earth Sciences, vol. 36, no. 3, pp. 207-214, 2003.

[8] K. A. P. Tokam, C. T. Tabod, A. A. Nyblade, J. Julia, D. A. Wiens, and M. Pasyanos, "Structure of the crust beneath Cameroon, West Africa, from the joint inversion of Rayleigh wave group velocities and receiver functions," Geophysical Journal International, vol. 183, no. 2, pp. 1061-1076, 2010.

[9] H. P. Chan, C. P. Chang, and P. D. Dao, "Geothermal anomaly mapping using Landsat ETM+ data in Ilan plain, northeastern Taiwan," Pure and Applied Geophysics, vol. 175, no. 1, pp. 303323, 2018.

[10] E. N. Nsifa, Magmatism and geodynamic evolution from Archean to of the northwestern edge of the Congo Craton (Ntem Complex) in southwestern Cameroon Sud-Ouest Cameroun, [Ph.D. thesis], University of Yaoundé I, Yaoundé, 2005.

[11] P. G. Kamto, W. Lemotio, A. P. K. Tokam, and L. Yap, "Combination of terrestrial and satellite gravity data for the characterization of the southwestern coastal region of Cameroon: appraisal for hydrocarbon exploration," International Journal of Geophysics, vol. 2021, Article ID 5554528, 14 pages, 2021.

[12] R. C. Andrés and G. Vargas-Cuervo, "Determination of hydrothermal prospects in Paipa geothermal region (Boyacá, Colombia) using remote sensing and field data," Earth Sciences Research Journal, vol. 23, no. 4, pp. 265-282, 2019.

[13] J. Uwiduhaye, G. Sakindi, H. Saibi, and B. A. Cherkose, "Subsurface geoelectrical structure from 3-D inversion of magnetotelluric data of Gisenyi geothermal field, western part of Rwanda," Journal of Applied Geophysics, vol. 186, 2021.

[14] H. Saibi, M. Bodruddoza Mia, M. Bierre, and M. Alkamali, "Application of remote sensing techniques to geothermal exploration at geothermal fields in the United Arab Emirates," Arabian Journal of Geosciences, vol. 14, no. 13, p. 1251, 2021.

[15] R. M. K. Petou, M. L. C. Owona Angue, N. Nfor, and E. Manguelle-Dicoum, "3D modelling from new and existing gravity data of an intrusive body in the northern part of Kribi-campo sub-basin in Cameroon," International Journal of Geosciences, vol. 8, no. 8, pp. 984-1003, 2017.

[16] N. Nfor, M. L. C. Owona Angue, R. M. K. Petou, D. Bisso, and J. K. Piameu, "Magnetotelluric investigation of the geo-tectonic stability of campo-Ma'an area in South Cameroon," International Journal of Geosciences, vol. 8, pp. 1427-1441, 2017.

[17] N. Nfor, O. Angue Marie Louise Clotilde, K. Petou Rokis Malquaire, M. D. Eliezer, L. Tsakou Julyo Achille, and P. Kwagag Jöel, "A comparative geophysical study of the SedimentaryMetamorphic contacts in the Douala and Kribi-campo SubBasins of Cameroon," Trends Journal of Sciences Research, vol. 3, no. 1, pp. 33-51, 2018.

[18] Njingti-Nfor, O. A. M. Louise, K. P. R. Malquaire, B. Dieudonné, and L. T. J. Achille, "Application of coefficient of anisotropy to the geophysical prospecting of campo-Ma' an 
area of the Ntem complex in Cameroon," Open Journal of Geology, vol. 7, pp. 1801-1818, 2017.

[19] O. A. M. L. Clotilde, C. T. Tabod, N. Séverin, K. J. Victor, and T. K. A. Pierre, "Delineation of lineaments in South Cameroon (Central Africa) using gravity data," Open Journal of Geology, vol. 3, no. 5, pp. 331-339, 2013.

[20] J. P. Nzenti, "Neoproterozoic alkaline meta-igneous rocks from the Pan-African North Equatorial Fold Bel (Yaounde, Cameroon): biotitites and magnetite rich pyroxenites," Journal of African Earth Sciences, vol. 26, no. 1, pp. 37-47, 1998.

[21] T. Ngnotué, J. P. Nzenti, P. Barbey, and F. M. Tchoua, "The Ntui-Betamba high-grade gneisses: a northward extension of the Pan-African Yaounde gneisses in Cameroon," Journal of African Earth Sciences, vol. 31, no. 2, pp. 369-381, 2000.

[22] J. R. L. Allen, "Studies in fluviatile sedimentation: Bars, barcomplexes and sandstone sheets (low-sinuosity braided streams) in the brownstones (L. devonian), welsh borders," Sedimentary Geology, vol. 33, no. 4, pp. 237-293, 1983.

[23] E. Manguelle-Dicoum, Geophysical study of the superficial and deep structures of the Mbalmayo region (Cameroon), [Ph.D. thesis], University of Yaoundé 1, Faculty of Sciences, Cameroon, 1998.

[24] S. Mbom-Abane, Geophysical investigation on the edge of the Congo craton (Abong-Mbang/Akonolinga region, Cameroon) and structural implications, [Ph.D. thesis], University of Yaoundé I, Faculty of Science, Cameroon, 1997.

[25] J. Gazel and C. Giraudie, "Descriptive note on the AbongMbang west region of the reconnaissance map," Bulletin of the Directorate of Mining and Geology of Cameroon, vol. 5, p. 29, 1965.

[26] F. Koumetio, Geophysical contribution by the gravimetric method to the study of the deep structures of the western margin of the Congo Craton in the region of Kribi (Cameroon), [Ph.D. thesis], 3rd cycle. University of Yaoundé, Cameroon, 2004.

[27] L. Cagniard, "Basic theory of the MAGNETO-TELLURIC method of geophysical prospecting," Geophysics, vol. 18, no. 3, pp. 605-635, 1953.

[28] L. S. Georgsson, Geophysical methods used in geothermal exploration, United Nations University Geothermal Training Programme Orkustofnun, Reykjavik, Iceland, 2009.

[29] G. Chander, B. L. Markham, and D. L. Helder, "Summary of current radiometric calibration coefficients for Landsat MSS, TM, ETM+, and EO-1 ALI sensors," Remote Sensing of Environment, vol. 113, no. 5, pp. 893-903, 2009.

[30] H. Ren, C. du, R. Liu et al., "Atmospheric water vapor retrieval from Landsat 8 thermal infrared images," Journal of Geophysical Research: Atmospheres, vol. 120, no. 5, pp. 1723-1738, 2015.

[31] J. A. Sobrino, J. C. Jiménez Muñoz, and L. Paolini, "Land surface temperature retrieval from LANDSAT TM 5," Remote Sensing of Environment, vol. 90, no. 4, pp. 434-440, 2004.

[32] J. C. Jiménez-Muños and J. A. Sobrino, "A generalized singlechannel method for retrieving land surface temperature from remote sensing data," Journal of Geophysical Research, vol. 108, no. D22, pp. 1-9, 2003.

[33] D. A. Artis and W. H. Carnahan, "Survey of emissivity variability in thermography of urban areas," Remote Sensing of Environment, vol. 12, no. 4, pp. 313-329, 1982.

[34] K. Vozoff, "The magnetotelluric method in the exploration of sedimentary basins," Geophysics, vol. 37, no. 1, pp. 98-141, 1972.
[35] H. Saibi, S. Khosravi, B. A. Cherkose, M. Smirnov, Y. Kebede, and A. Fowler, "Magnetotelluric data analysis using 2D inversion: A case study from Al- Mubazzarah Geothermal Area (AMGA), Al-Ain, United Arab Emirates," Heliyon, vol. 7, no. 6, article e07440, 2021.

[36] G. Ussher, C. Harvey, R. Johnstone, and E. Anderson, "Understanding the resistivities observed in geothermal systems," in Inproceedings world geothermal congress, pp. 1915-1920, Japan, 2000.

[37] D. B. Hoover and C. L. Long, Audio-Magnetotelluric Methods in Reconnaissance Geothermal Exploration, US. Geological Survey, Branch of Theoretical and Applied Geophysics, Denver Federal Center, Denver, Colorado 80225, USA, 1976.

[38] M. T. Mellon, B. M. Jakosky, H. H. Kieffer, and P. R. Christensen, "High-Resolution Thermal Inertia Mapping from the Mars Global Surveyor Thermal Emission Spectrometer," Icarus, vol. 148, no. 2, pp. 437-455, 2000.

[39] W. Wu, L. Zou, X. Shen et al., “Thermal infrared remotesensing detection of thermal information associated with faults: a case study in Western Sichuan Basin, China," Journal of Asian Earth Sciences, vol. 43, no. 1, pp. 110-117, 2012.

[40] G. Norini, G. Groppelli, R. Sulpizio et al., "Structural analysis and thermal remote sensing of the Los Humeros volcanic complex: implications for volcano structure and geothermal exploration," Journal of Volcanology and Geothermal Research, vol. 301, pp. 221-237, 2015.

[41] J. C. Jiménez-Muñoz, J. Cristóbal, J. A. Sobrino, G. Sòria, M. Ninyerola, and X. Pons, "Revision of the single-channel algorithm for land surface temperature retrieval from Landsat thermal-infrared data," IEEE Transactions on Geoscience and Remote Sensing, vol. 47, no. 1, pp. 339-349, 2009.

[42] İ. Çağlar and M. Demirörer, "Geothermal exploration using geoelectric methods in Kestanbol, Turkey," Geothermics, vol. 28, no. 6, pp. 803-819, 1999.

[43] C. L. Hardwick and D. S. Chapman, "Geophysical delineation of the crater bench, Utah, geothermal system," Transactions Geothermal Resource Council, vol. 35, pp. 801-804, 2011.

[44] X. Wang, L. He, X. Zhao, and N. Yu, Application of Geophysical Methods to the Geothermal Investigation, Stanford University, Stanford, California, 2015.

[45] T. J. Lee, Y. Song, T. Uchida, Y. Mitsuhata, and S. Oh, "Interpretation of 3-D magnetotelluric data including sea effect for geothermal exploration in Pohang, Korea," Asian Geothermal Symposium, pp. 139-143, 2004. 